\title{
КІСТКИ ТВАРИН У ВОЛГО-ДОНСЬКИХ БАБИНСЬКИХ ПОХОВАННЯХ ЯК КУЛЬТУРНО-ХРОНОЛОГІЧНІ ІНДИКАТОРИ ТА МАРКЕРИ ГОСПОДАРСЬКОЇ МОДЕЛІ
}

\begin{abstract}
Pеферат: Статтю присвячено характеристиці та аналізу такої ознаки поховального обряду волго-донської бабинської культури (XXII-XX cal. BC), як «кістки тварин». Їх розміщення в могилі та анатомічний склад є надійними культурно-хронологічними індикаторами. «Візитівкою» культури $\epsilon$ покладення в могилу кісток кінцівок дрібної та великої рогатої худоби - ДРХ, ВРХ та ДРХ/ВРХ. Знаходяться вони, як правило, перед померлим, близько лівої руки. Аналіз кількісного співвідношення $i$ територіального поширення поховань з кістками ДРХ $і$ ВРХ дозволяє попередньо охарактеризувати господарську модель носіїв волго-донської бабинської культури.
\end{abstract}

Ключові слова: культурний круг Бабине, волго-донська бабинська культура, поховання, кістки тварин ДРХ і ВРХ, хронологія, господарська модель.

Вступ. Волго-донська бабинська культура (ВДБК) обіймала східну частину блоку посткатакомбних культурних утворень [Мимоход 2005]. У процесі виділення пам'яток фіналу середньої бронзи в Нижньому Поволжі ВДБК пройшла шлях від криволуцької культурної групи [Мимоход 2004; 2010] до повноцінної культури [Мимоход 2013; 2014]. 3 їі виокремленням концепція Р.О. Литвиненко культурного кола Бабине [Литвиненко 2008; 2009; 2009a; 2011] набула завершеності. На сьогоднішні до складу кола Бабине входять волго-донська, дніпро-донська та дніпро-прутська бабинські культури. Культурне коло Бабине, разом з культурним колом Лола, складають структуру всього посткатакомбного світу [Мимоход 2013б; 2016; 2017; 2018; Литвиненко 2014, с. 208; 2015, с. 113; 2018].

Свого часу, коли в нульових роках нинішнього століття було виділено культурні утворення в східній і південно-східній частинах посткатакомбного блоку, важливу роль відіграв такий елемент поховального обряду, як «кістки тварин» (КТ). Так, своєрідною «візитівкою» лолінської культури Північно-західного Прикаспію виявилося покладання в могилу лопаток ДРХ [Мимоход 2003, с. 104; 2007, с. 145; 2007a, c. 119-120; 2013a, c. 39-45].

Процес виокремлення посткатакомбних пам'яток в Нижньому Поволжі був запущений Е.С. Шарафутдіновою. В регіоні вона виділила групу поховань фіналу середньої бронзи, в якій опинилися й поховання ВДБК. Попри те, що добірка виявилася неоднорідною як в хронологічному, так і в культурному відношеннях, дослідниця окремо звернула увагу на те, що кістки ніг ДРХ і ВРХ в могилах виступають характерною ознакою нижньоволзьких комплексів фіналу середньої бронзи [Шарафутдинова 1999, с. 159; 2001, с. 149]. Два роки по тому О.В. Кияшко на основі нечисленних доступних йому даних відокремив посткатакомбні поховання Нижнього Поволжя в рамках локального варіанту культури багатоваликової кераміки (нині Бабине) [Кияшко 2003, с. 30, 31]. У цій праці дослідник також відзначив присутність кісток ніг ДРХ в похованнях виділеної групи й надав ряд відповідних ілюстрацій [Кияшко 2003, с. 30, рис. 2, 3]. Р.О. Литвиненко, аналізуючи «східну периферію бабинського осередку культурогенези», одним з їі компонентів представив групу поховань чисельністю «більше п’яти десятків» посткатакомбного періоду в нижньоволзькому регіоні. В якості іiі діагностичної ознаки він указав на супровід поховань напутньої їжею, а саме м'ясом дрібних копитних (без уточнення анатомічного складу кісток) [Литвиненко 2004, с. 103]. У цьому ж збірнику мною була предметно обгрунтовано культурну самостійність посткатакомбних поховань Нижнього Поволжя (близько 70 поховань) та запропоновано для неї робочу назву «криволуцька культурна група» [Мимоход 2004, с. 112]. Як і раніше для лолінської культури [Мимоход 2003, с. 104], кістки ДРХ в похованнях криволуцької культурної групи (нині ВДБК) були названі «своєрідною візитівкою», а також було конкретизовано їхній анатомічний склад і місце розташування в могилі: «Как правило, помещались одна или две 
ноги ... Они почти всегда расположены перед умершим у локтя или предплечья правой ${ }^{1}$ руки» [Мимоход 2004, с. 109]. Подальші дослідження вже 3 повною та обробленою базою даних і в рамках таксону «волго-донська бабинська культура» лише підтвердили ці спостереження [Мимоход 2013, с. 169; 2014, с. 103, 105].

Попри те, що згадки кісток ДРХ в похованнях фіналу середньої бронзи Нижнього Поволжя, як культурно-хронологічного індикатора, налічує вже 20 років, всі вони мають тезовий характер в рамках загальної характеристики комплексів даного періоду в регіоні. Це дисонує, наприклад, 3 лолінською посткатакомбною культурою, для якої присвячена означеній проблемі праця вийшла незабаром після виділення культури та в один рік 3 публікацією розгорнутого обгрунтування іiі існування [Мимоход 2007; 2007а]. Спеціальних досліджень, предметом яких був би аналіз ознаки «кістки тварин в похованнях», як культурно-хронологічного індикатора, для доби бронзи фактично немає. Винятком є стаття О.В. Кузьміної, в якій здійснено аналіз залишків напутньої їжі в контексті поховального обряду абашевської культури [Кузьмина 2000]. Важливість цієї праці для нашої теми полягає в тому, що дослідницею було проаналізовано серію поховань культури, що є синхронною першій та другій фазам посткатакомбного блоку, якими й датується ВДБК.

Мета даної статті - це не тільки заповнити наявну прогалину у посткатакомбній проблематиці Нижнього Поволжя, а й показати, що суттєве культурно-хронологічне навантаження можуть мати не лише артефакти та специфічні риси обряду. Його може мати, здавалося б, така прохідна і «неграюча» деталь поховального комплексу, як «кістки тварин» ${ }^{2}$.

Класифікація. На сьогодні налічується 204 поховань волго-донської бабинської культури. 3 них 125 поховань супроводжувалися КТ (61,3\%) (рис. 1). Переважна більшість кісток належать ДРХ і ВРХ - 97,5\% від усіх поховань з КТ ${ }^{3}$. У двох випадках в джерелах було зазначено, що поховання супроводжувалися кістками тварин, без уточнень яких саме ${ }^{4}$. Тільки в одному комплексі Ріпний 7/13 разом 3 кістками ДРХ було виявлено колінну чашечку коня [Глебов 2004, с. 98].

Комплекси з КТ було розбито на типи, залежно від анатомічного й видового складу кісток.

Tun 1. Кістки ніг/ноги ДРХ (рис. 2, 3, табл. 1) найчастіше супроводжують поховання ВДБК і є одним з елементів наочного образу культури. У видовому відношенні переважна їх більшість, швидше за все, належить вівці.

Tun 2. Кістки ніг BPX (рис. 4, табл. 1) трапляються рідше, але також виступають в якості маркера поховального обряду ВДБК, що добре розпізнається.

Tun. 3. Кістки ніг ВРX та ДРX (рис. 5: 1-5, табл. 1). Поєднуються в одному похованні, причому, як правило, вони лежать разом, що не залишає сумніву в їхньому семантичному зв'язку.

${ }^{1}$ У тексті цієї праці є прикра помилка/описка [Мимоход 2004, с. 109]: слід читати не «у ліктя або передпліччя правої руки», а у «ліктя або передпліччя лівої руки». Лівобічне положення скелета було домінуючим у поховальній обрядовості ВДБК, і кістки зазвичай розташовували у випростаної уздовж тіла лівої руки.

${ }^{2}$ Як уже зазначалося, раніше ця тема була розкрита на прикладі лолінської культури Північнозахідного Прикаспію [Мимоход 2007a; 2013, с. 39-46]. У даній праці, наскільки дозволяє матеріал, зберігається алгоритм статті по КТ в Лолі, з огляду на очевидні структурні відповідності в їхньому використанні в поховальному обряді культурних утворень посткатакомбного блоку.

33 аналізу виключено поховання, в яких виявлено тільки астрагали ДРХ. Відома специфіка використання цих предметів більше наближає їх до категорії «артефакт», ніж до «КТ». 3 урахуванням комплексів з астрагалами, в яких немає кісток тварин, кількість поховань зростає до 128, що не $\epsilon$ принциповим. При виділенні типів КТ, у випадку виявлення їх в одному комплексі з альчиками (4 випадки), останні ігнорувались. Показово, що знаходились вони окремо від залишків напутньої їжі.

${ }^{4}$ Видова належність та анатомічний склад КТ визначено переважно авторами розкопок. В публікаціях вже трапляються, хоча й поодиноко, визначення КТ з комплексів ВДБК, що зроблені археозоологами [Косинцев, Рослякова 1999, с. 49; 2006, с. 79, 80; Глебов, 2004, с. 63, 98]. 
Тип. 4. Кістки ніг і тазу ДРХ (рис. 5: 6-8, табл. 1).

Tun. 5. Ребра та хребиі ДРХ (рис. 5: 9-12, табл. 1).

Тип. 6. Кістки ніг і лопатки ДРХ (рис. 5: 13-15, табл. 1).

Типи 4 і 6 близько стоять до найпоширенішого типу 1. Очевидно, що в першому випадку в могилу поміщалися задні кістки ніг з тазом, у другому - передні з лопатками.

Решту типів представлено поодинокими комплексами:

Тип 7. Лопатка ДРХ (рис. 5: 16, табл. 1).

Tun 8. Роги та верхня частина черепа BРX (рис. 4: 2, табл. 1).

Тип. 9. Щелепа ДРХ (рис. 5, 17, табл. 1).

Tun 10. Череп і нога ДРХ (рис. 5, 18, табл. 1).

\begin{tabular}{|l|c|c|}
\hline \multicolumn{1}{|c|}{$\begin{array}{c}\text { Типи комплексів } \\
\text { 3 КТ }\end{array}$} & Кількість комплексів & $\begin{array}{c}\text { Питома вага (\%) від } \\
\text { загальної кількості } \\
\text { поховань ВДБК 3 КT }\end{array}$ \\
\hline Тип 1 & 79 & 63,2 \\
\hline Тип 2 & 15 & 12 \\
\hline Тип 3 & 8 & 6,4 \\
\hline Тип 4 & 4 & 3,2 \\
\hline Тип 5 & 4 & 3,2 \\
\hline Тип.6 & 4 & 3,2 \\
\hline Тип 7 & 1 & 0,8 \\
\hline Тип 8 & 1 & 0,8 \\
\hline Тип 9 & 1 & 0,8 \\
\hline Тип 10 & 1 & 0,8 \\
\hline Дані щодо \\
$\begin{array}{l}\text { анатомічного та/або } \\
\text { видового складу } \\
\text { відсутні }\end{array}$ & 7 & 5,6 \\
\hline Разом & \\
\hline
\end{tabular}

Таблиця 1. Кількісний розподіл типів комплексів з КТ (корелюється з рис.7)

Для з'ясування культурно-хронологічної значущості комплексів з КТ у волго-донській бабинській обрядовості необхідно: 1) здійснити аналіз ситуативного розміщення типів комплексів у могилі й відносно до похованого, порівняти отримані результати, а також самі типи комплексів, з відповідними даними діахронних і синхронних культур; 2) наскільки можливо, виявити хронологічні закономірності функціонування виділених типів у рамках хронології ВДБК; 3) простежити особливості територіального поширення комплексів з КТ.

Культурно-хронологічні індикатори. Волго-донська бабинська культура демонструє чіткі принципи розміщення КТ в могилі. Загальна тенденція - приуроченість кісток до тіла померлого (рис. 6). Основна зона розміщення - близько лівої руки (табл. 2). Тут знаходиться переважна більшість всіх типів КТ (рис. 6, табл. 2). Причому, в рамках цієї зони виділяються дві ділянки, найбільш насичені комплексами. Йдеться про район ліктьового суглоба та кисті (рис. 6).

Якщо розглянути розташування КТ за типами, отримаємо наступну картину (табл. 2). Там, де померлих супроводжують тільки ноги ДРХ, ВРХ, ДРХ/ВРХ (типи 1-3), вони здебільшого розміщаються в зоні найвищої концентрації (близько лівої руки): відповідно, 79,7\%, 73,3\%, 75\% (від кількості всіх комплексів за кожним типом). Ще більш показовою $\epsilon$ ситуація 3 типом 6 (кістки ніг і лопатки ДРХ) (рис. 5: 13-15). Тут всі чотири комплекси знаходяться попереду небіжчика, поблизу лівої руки (табл. 2, рис. 6: 2). Тип 4 (ноги і таз ДРХ) (рис. 5: 6-8) теж є нечисленним (табл. 2), але проявляє аналогічну тенденцію, хоча в одному комплексі задні кінцівки було виявлено в нестандартній зоні - біля голови (рис. 5: 6, 
7, 2) ${ }^{5}$. У свою чергу, кількісно найбільше відхилень від норми (зона близько лівої руки) демонструє тип 1 (кістки ніг ДРХ), хоча за питомою вагою він проявляє високу ступінь стандартизації. Це не дивно, тому що він $є$ найчисленнішим (табл. 1, 2). Мабуть, тому тип 1 , а також другий за чисельністю тип 2, трапляються в зоні, в якій поки не відомі інші комплекси з КТ. Йдеться про позицію «на відстані від скелета» (табл. 2, рис. 2: 20, 24; 4: 2 , 7). Причому, в цій зоні перебувала нечисленна, втім помітна частина комплексів; $5,1 \%$ типу 1 і 6,6\% типу 2. Решту типів у могилах ВДБК прив'язано винятково до скелету (рис. 6: 2).

\begin{tabular}{|l|c|c|c|c|c|c|}
\hline $\begin{array}{l}\text { Зона розміщення } \\
\text { КТ у похованні }\end{array}$ & Тип 1 & Тип 2 & Тип 3 & Тип 4 & Тип 5 & $\begin{array}{c}\text { Типи } \\
\text { 6-9 }\end{array}$ \\
\hline $\begin{array}{l}\text { Поблизу лівої руки } \\
\text { перед померлим }\end{array}$ & 56 & 8 & 6 & 2 & 3 & 2 \\
\hline Поблизу черепа & 3 & 1 & - & 1 & - & 1 \\
\hline $\begin{array}{l}\text { Поблизу плеча та } \\
\text { ліктя правої руки (за } \\
\text { спиною) }\end{array}$ & 2 & 1 & - & 1 & - & 1 \\
\hline За спиною і тазом & 2 & - & - & - & - & 1 \\
\hline $\begin{array}{l}\text { Поблизу живота, на } \\
\text { стегнових кістках, } \\
\text { поблизу колін }\end{array}$ & 3 & - & 1 & - & - & - \\
\hline $\begin{array}{l}\text { Між стегновими та } \\
\text { гомілковими } \\
\text { кістками і поблизу } \\
\text { стоп в }\end{array}$ & 3 & - & 1 & - & - & - \\
\hline $\begin{array}{l}\text { На відстані від } \\
\text { скелета }\end{array}$ & 6 & 1 & - & - & - & - \\
\hline Не встановлено & 7 & & & & & \\
\hline
\end{tabular}

Таблиця 2. Розміщення різних типів КТ у похованнях ВДБК

Таким чином, є всі підстави стверджувати, що анатомічний та видовий склад КТ в волго-донських бабинських похованнях $\epsilon$ культурним індикатором. Своєрідною «візитівкою» виступають кістки ніг ДРХ. Це - найчисленніший тип, який трапляється в 63,2\% випадках від всіх поховань з КТ (табл. 1). Примикають до них типи 2 і 3 (кістки ніг ВРX та кістки ніг ВРХ та ДРХ). Їх значно менше, ніж комплексів 1-го типу, вони рідше, проте стабільно трапляються в похованнях ВДБК. Типи 4 і 6 , як уже зазначалося, по суті, $\epsilon$ варіаціями типу 1 , але $з$ додаванням до задніх кінцівок кісток тазу, а до передніх - лопаток. Можна не сумніватися, що у носіїв волго-донських бабинських традицій у поховальному ритуалі особливий семіотичний і семантичний статус мали саме ноги парнокопитної рогатої худоби, з явним домінуванням ДРХ. Якщо об’єднати в одну групу типи 1-4, 6, які й пов'язані з цим статусом, то вони складуть 88\% від усіх поховань з КТ.

Виявлена тенденція видається більш ніж виразною, особливо в порівнянні 3 синхронними посткатакомбними культурами. У лолінській культурі ситуація принципово інша. Тут фактично немає кісток ВРХ, а найбільшу значимість в поховальному обряді мають лопатки ДРХ, які виявлено у 67\% лолінських комплексів з КТ. Поховання, в яких виявлено кістки кінцівок ДРХ, складають лише 11,8\%, а їх поява в лолінській культурі, як показує картографія, здебільшого пов'язана 3 міжкультурними контактами між Лолою і ВДБК [Мимоход 2007a, с. 125; 2013, с. 45]. Цим же фактором пояснюється і наявність одного

${ }^{5}$ У перспективі цікавими стануть дослідження археозоологів. Зокрема, чи $є$ які-небудь відмінності в розміщенні задніх та передніх ніг копитних у похованнях? На прикладі типів з КТ 4 і 6 , які без спеціального аналізу розуміються як передня і задня частини тіла, пов'язані з кінцівками тварини, відмінності простежуються. 
волго-донського бабинського поховання з чисто лолінським типом КТ (тип 7, лопатка ДРХ). Не дивно, що цей комплекс - Крива Лука XI 4/5 (рис. 5: 16) - знаходився на межі ареалів лолінської та волго-донської бабинської культур (рис. 1) ${ }^{6}$.

Також культурна специфіка у використанні КТ у ВДБК добре проявляється при зіставленні з аналогічною ознакою дніпро-донської бабинської культури (ДДБК). Тут є серія поховань з частинами хребта ДРХ [Литвиненко, Зарайская 2004, с. 223; Литвиненко 2006а, с. 178]. У Волго-Донському Бабиному відомий лише один комплекс, в якому виявлено кістки хребта - Вертячий 7/24 (рис. 5: 9). Він знаходиться на лівому березі Нижнього Дону (рис. 1), де окреслюється одна $з$ головних контактних зон ДДБК і ВДБК [Литвиненко 2012; 2019, c. 325, 327]. Найхарактернішою ознакою для поховань Дніпро-Донського Бабиного є розміщення в могилах так званих «шкур», які представлено черепами та кістками ніг ВРХ, значно рідше - ДРХ і коня [Писларий 1991, с. 57; Литвиненко 2006, с. 224; 2006а с. 182; 2007, с. 160; 2009б, с. 83, 84; Грищук 2019, с. 48]. Такі комплекси з КТ не є характерними для ВДБК. В їі матеріалах відомо лише одне поховання (Смєловка п. 111), де виявлено кістки ноги та череп ДРХ (тип 10) (рис. 5: 18).

Розміщення кісток в могилах ВДБК виступає своєрідним культурним i, частково, надкультурним маркером. Справа в тому, що ця культура $є$ найсхіднішою в Бабинському колі. Саме іï носії найчастіше контактували з групами культурного кола Лола. ВДБК на півдні межує з лолінською культурою, а на сході - 3 волго-уральською культурною групою [Мимоход 2013a, илл. 123]. Як уже зазначалося, зона найвищої концентрації КТ у волгодонських бабинських похованнях локалізується поблизу лівої руки, особливо в районі ліктьового суглоба і кисті (рис.6, табл. 2). В культурних утвореннях лолінського кола (лолінська культура, кубанська, волго-уральська й архонська групи) можна спостерігати аналогічну пріоритетну зону в розміщенні кісток тварин відносно похованого [Мимоход 2006 с. 250, 251; 2007a; 2013a, с. 42; Кореневский, Мимоход 2011, с. 41].

Таким чином, ВДБК, за ознакою «розміщення КТ відносно скелета» демонструє значну спільність 3 культурним колом Лола, аніж 3 колом Бабине. Ця різниця стане ще очевиднішою, якщо врахувати, що для ДДБК є характерною відокремленість кісток тварин від померлих, аж до розміщення їх між дерев'яною рамою та стінкою ями, а також винесення за межі поховання, на підкурганні майданчики [Литвиненко 2006а, с. 182; 2009б, с. 83, 84]. Натомість, попри виявлені відмінності, ВДБК є невід’ємною складовою культурного кола Бабине, про що свідчать численні інші ознаки в обрядово-інвентарному комплексі. I навіть на рівні ознаки «кістки тварин» ця спільність теж простежується. Якщо місце розміщення кісток в могилах ВДБК демонструє очевидні лолінські традиції, то видовий склад $є$ ближчим до ДДБК: у Волго-Донському Бабиному добре представлено кістки ВРХ, фактично невідомі в матеріалах лолінської культури [Мимоход 2007a, с. 119; 2013a, с. 45].

Кістки тварин у волго-донських бабинських похованнях також виступають хронологічним індикатором. Це, насамперед, обгрунтовується хронологією самої ВДБК [Мимоход 2010; 2013, с. 169, 172, 173; 2014, с. 109, 115; 2018a, с. 118, 119]. Стратиграфічні дані визначають їі позицію між катакомбними старожитностями та пам'ятками початку доби пізньої бронзи (горизонт колісничних культур) в рамках фіналу середнього бронзового віку. У ряді поховань ВДБК є серія артефактів, що вузько датуються: кістяні пряжки (рис. 2: 6, 27, 3, 5, 11, 13), дворіжкове і пелюстковоподібне намисто, кам'яний брусок з двома перетяжками, бронзовий напівсферичний ковпачок з отвором (рис. 3: 17), керамічні корчі (рис. 3: 19) тощо. За аналогією з чітко визначеною хронологією ДДБК і лолінської культури, діапазон існування ВДБК можна впевнено синхронізувати з першою та другою фазами блоку

${ }^{6}$ Аналогічно в контактній зоні лолінської та дніпро-донської бабинської культур можна знайти поодинокі випадки виявлення лолінського типу КТ (лопатки ДРХ) в дніпро-донській бабинській культурі [Литвиненко 2005, с. 76], а бабинського типу КТ (хребет ДРХ) - в лолінській [Мимоход 2007 a, c. 125]. 
Донецький археологічний збірник. - 2019. - № 22. - С. 21-45.

посткатакомбних культурних утворень, які відповідають першому та другому періодам Дніпро-Донського Бабиного і Лоли.

На сьогодні ми маємо 12 радіовуглецевих дат ВДБК (табл. 3), які дозволяють попередньо окреслити час іiі існування в цифрових значеннях.

\begin{tabular}{|c|c|c|c|c|c|}
\hline № & Пам’ятка & $\begin{array}{c}\text { Шифр } \\
\text { лабораторії }\end{array}$ & Матеріал & Дата ВР & $\begin{array}{c}\text { Дата ВС } \\
\text { Вірогідність } \\
68,2 \%\end{array}$ \\
\hline 1. & Линеве к.8 п.2 & $\mathrm{Ki}-12886$ & $\begin{array}{l}\text { Кістка } \\
\text { людини }\end{array}$ & $3590 \pm 50$ & $2030-1880$ \\
\hline 2. & Линеве к.6 п.6 & $\mathrm{Ki}-12876$ & $\begin{array}{l}\text { Кістка } \\
\text { людини }\end{array}$ & $3825 \pm 50$ & $2350-2190$ \\
\hline 3. & Паницьке 6 к.4 п.3 & Ki-13003 & $\begin{array}{l}\text { Фрагмент } \\
\text { кераміки }\end{array}$ & $3600 \pm 90$ & $2130-1810$ \\
\hline 4. & Паницьке 6 к.4 п.3 & $\mathrm{Ki}-13004$ & $\begin{array}{l}\text { Астрагал } \\
\text { ДРХ }\end{array}$ & $3530 \pm 70$ & $1940-1740$ \\
\hline 5. & Грачівка II к.10 п.1 & Лe-6544 & $\begin{array}{l}\text { Кістка } \\
\text { людини }\end{array}$ & $3820 \pm 70$ & $2410-2140$ \\
\hline 6. & Утьовка V к.4 п.1 & AA-53802 & $\begin{array}{l}\text { Кістка } \\
\text { людини }\end{array}$ & $3583 \pm 52$ & $2030-1870$ \\
\hline 7. & $\begin{array}{l}\text { Євстратівський II к.2 } \\
\text { п.2 }\end{array}$ & Ki-14742 & $\begin{array}{l}\text { Кістка } \\
\text { людини }\end{array}$ & $3670 \pm 70$ & $2140-1940$ \\
\hline 8. & $\begin{array}{l}\text { Євстратівський II к.4 } \\
\text { п.3 }\end{array}$ & ИГАН-3731 & $\begin{array}{l}\text { Кістка } \\
\text { людини }\end{array}$ & $3560 \pm 100$ & $2030-1750$ \\
\hline 9. & Калинівський I к.1 п.4 & ИГАН-3730 & $\begin{array}{l}\text { Кістка } \\
\text { людини }\end{array}$ & $3420 \pm 90$ & $1880-1620$ \\
\hline 10. & $\begin{array}{l}\text { Скворцовка к.5 п.3 } \\
\text { скелет } 1\end{array}$ & Лe-7684 & $\begin{array}{l}\text { Кістка } \\
\text { людини } \\
\end{array}$ & $3700 \pm 90$ & $2210-1940$ \\
\hline 11. & $\begin{array}{l}\text { Скворцовка к.5 п.3 } \\
\text { скелет } 1\end{array}$ & $\mathrm{Ki}-16261$ & Кістка ДРХ & $3400 \pm 40$ & $1770-1630$ \\
\hline 12. & $\begin{array}{l}\text { Красносамарський IV } \\
\text { к.3 п. } 10\end{array}$ & AA-37042 & $\begin{array}{l}\text { Кістка } \\
\text { людини }\end{array}$ & $3594 \pm 45$ & $2020-1890$ \\
\hline
\end{tabular}

Примітка: 1-4 - дати за [Ковалюх, Мимоход 2007, табл. 1]; 5 - дата за [Черных, Орловская 2004, табл. 3, 4; Кузнецов и др. 2018, табл. 3]; 7-9 - дати за [Мимоход 2010] 10-11 - дати за [Моргунова и др. 2010, с. 70, табл. 2]; 6, 12 - дата за [Кузнецов и др. 2018, табл. 3].

Таблиця 3. ${ }^{14} \mathrm{C}$ дати волго-донської бабинської культури

Всі дати показують високу ступінь збіжності. Підсумовування даних окреслює калібрований інтервал в одну сигму в межах XXII-XVIII ст. до н.е. Саме такий відрізок дають більш презентабельні вибірки радіовуглецевих дат лолінської та бабинської культур доно-прутського регіону [Мимоход 2011], що дозволяє підтвердити окреслені лінії синхронізації. 3 урахуванням того, що хронологічний інтервал ВДБК коротше діапазонів ДДБК і Лоли, час існування посткатакомбних пам'яток нижньоволзького регіону слід звузити до XXII-XX ст. до н.е. Саме для цього періоду є характерною традиція покладання в могили ВДБК кісток ніг ДРХ і ВРХ.

Тут слід зазначити один важливий момент. Хронологічним маркером виступає не стільки анатомічний склад КТ, скільки розміщення їх відносно померлого. Справа в тому, що кістки ніг ДРХ починають використовувати в поховальному обряді на Нижній Волзі в попередній, катакомбний період. У похованнях розвиненого, а здебільшого пізнього, етапів 
середньої бронзи, присутні кістки кінцівок ДРХ, але положення їх в могилі прямо протилежне посткатакомбній традиції. Досить порівняти акумулятивні схеми їх розміщення в катакомбних і посткатакомбних похованнях нижньоволзького регіону (рис. 6, 8). У першому випадку є очевидною відокремленість КТ від тіла померлого. Вони локалізуються по кутах могили, біля стін, у вхідних шахтах. Лише двічі в нижньоволзьких катакомбних похованнях кістки ніг ДРХ перебували у «посткатакомбній» зоні - біля лівої руки. В якості культурно-хронологічних маркерів є показовими процентні співвідношення. У катакомбних похованнях кістки ніг ДРХ, розміщені в «посткатакомбній» позиції, складають лише 6,5\% від усіх врахованих поховань 3 цим типом КТ ${ }^{7}$. Аналогічний показник для ВДБК (тип 1) становить $80 \%$ від усіх комплексів з типом 1. Ситуація тут є принципово подібною до тієї, яку демонструють, наприклад, лолінська та пізня східноманичська катакомбна культури. У першому випадку більшість лопаток ДРХ локалізуються поблизу лівої руки, у другій - на відстані від скелета, під стінами, в кутах, вхідній шахті [Мимоход 2007а, рис. 4: 1-3; 2013а, илл. $23,1-3]^{8}$. Вочевидь, може йтися про структурні відмінності та подібності в розміщенні кісток тварин у похованнях носіїв катакомбних і посткатакомбних традицій ВолгоДонського регіону та Передкавказзя.

Повертаючись до відмінності положення кісток ніг ДРХ в похованнях ВДБК (фінал середньої бронзи) і катакомбних комплексах (пізній період середньої бронзи), слід звернути увагу на ще одну важливу культурно-хронологічну відмінність. У похованнях волго-донської катакомбної культури є виразною тенденція приуроченості ніг ДРХ до посудини (рис. 8). Кількість комплексів, коли КТ розташовано поруч з посудиною або в ній, становить 35\% від усіх врахованих поховань з кінцівками дрібних копитних. Серед 79 поховань ВДБК з типом 1 тільки у двох (Бережнівка I 4/3 та Симонівка 1/1) ноги ДРХ лежали поруч з посудиною, що становить лише 1,6\%. Причому ці поховання відносяться до раннього етапу ВолгоДонського Бабиного. Бережнівське поховання було справлене в катакомбі (рис. 3: 23). Цей тип могильної конструкції характерний для початкової фази ВДБК. Комплекс Симонівка 1/1 супроводжувався дуже архаїчним і рідкісним типом посуду для культурного кола Бабине корчею (рис. 3: 19). Такий посуд характерний тільки для раннього етапу дніпро-донської бабинської культури [Литвиненко 1999; 2006а, с. 176, табл. 3; 2016, с. 212; Кияшко, Ларенок 2019], так само вони датуються і у ВДБК. На дуже ранню позицію цих комплексів вказує й саме розміщення кінцівок ДРХ поруч 3 посудом, що, як зазначалося, $\epsilon$ культурнохронологічним маркером катакомбного часу. При цьому слід зазначити, що в комплексах Бережнівка I 4/3 і Симонівка 1/1 ноги ДРХ з посудиною не відокремлено від скелета, як в катакомбній традиції, а приурочено до тіла померлого (рис. 3: 19, 23), хоча і знаходяться вони в нетиповій для ВДБК зоні - у черепа (рис. 6). Цю зону частіше використовували для розміщення кінцівок вівці в катакомбний період (рис. 8).

Коли ми розглядаємо КТ у Волго-Донському Бабиному як хронологічний індикатор, то, без сумніву, він таким є для всього періоду існування культури. Однак серйозні труднощі виникають при співвіднесенні цієї ознаки 3 внутрішньою періодизацією ВДБК. На матеріалах лолінської культури показано, що в рамках триетапної періодизації добре простежується еволюція використання кісток ДРХ в поховальному обряді від раннього до пізнього періодів [Мимоход 2007a, с. 123, 124, рис. 4: 7-9; 2013a, с. 43, 44, прилож. 2, табл. 2 , илл. 23: 7-9 ${ }^{9}$. Зазначені труднощі для ВДБК - це проблема періодизації самої культури. В їі

7 Загалом було враховано 31 доступних мені по публікаціях поховань волго-донської катакомбної культури в Нижньому Поволжі, в яких виявлено кістки ніг ДРХ.

8 Така ж структура розташування КТ, зокрема, черепів характерна для західноманичської катакомбної культури [Гей 1995, рис. 11].

${ }^{9}$ У ДДБК ранній етап маркований серією комплексів зі «шкурами» (черепа та кістки ніг ВРХ, рідше - ДРХ і коня) [Литвиненко 2006, с. 224; 2006а с. 182; 2007, с. 160; 20096, с. 83, 84]. Втім, для розвиненого та пізнього етапів ДДБК ситуація 3 ознакою «КТ» в похованнях $\epsilon$ незрозумілою. Спеціальних досліджень на цю тему поки немає. 
розвитку впевнено можна виділити два етапи. Однак основу цього поділу становлять не стільки дані стратиграфії, скільки діагностичні риси поховального обряду та вузько датовані речі. Не можна сказати, що для волго-донських бабинських поховань не вистачає стратиграфічних даних. $\mathcal{C}$ численні випадки співвідношення поховань ВДБК з комплексами попереднього (катакомбного) i наступного (початок пізньої бронзи) періодів, які й визначають час їх існування в рамках фіналу доби середньої бронзи [Мимоход 2010, с. 158; 2013, с. 169; 2014, с. 109, 110]. Кількість стратиграфічних зв'язок між похованнями самої ВДБК складає 17 випадків, але проблеми внутрішньої періодизації вони не розв'язують. Справа полягає у яскраво вираженій безінвертарності волго-донських бабинських поховань. Такі комплекси складають 70,6\% від усіх поховань ВДБК. В результаті при створенні внутрішньої хронології доводиться прив'язуватися до вузько датованих артефактів i діагностичних рис поховального обряду, чітка хронологічна позиція яких зафіксована завдяки добре розробленій періодизації сусідніх культур: дніпро-донської бабинської та лолінської.

Наявність раннього етапу в розвитку ВДБК обгрунтовується присутністю в іï інвентарному комплексі кільцевих пряжок (рис. 2: 6, 27; 3: 13), бруска з двома перетяжками, дворіжкових та пелюстковоподібних намистин, кавказького імпорту (рис. 3: 17), наборів стрілоробів (рис. 4: 2), корч (рис. 3: 19), які дозволяють впевнено синхронізувати ранні пам'ятки ВДБК $з$ першими етапами дніпро-донської бабинської та лолінської культур. Швидше за все, до ранніх волго-донських бабинських поховань слід віднести й поховання у катакомбах (рис. 3: 20-23; 4: 12-14). Дані Лоли свідчать про те, що цей тип поховальної конструкції є характерним для найбільш архаїчних поховань [Мимоход 2007, с. 145; 2013a, с. 220].

У двох комплексах ВДБК знайдено кільцеві пряжки з бортиком (Линеве 6/6, Королі 4/3) (рис. 3: 5), які серійно представлено в похованнях другого етапу дніпро-донської бабинської культури. Наявність виробів цього типу у Волго-Донському Бабиному свідчить про те, що iï завершальний період є синхронним другому етапу ДДБК, а, відповідно, i другому етапу лолінської культури. Симптоматичним виглядає відсутність у волго-донських бабинських комплексах дводірчастих пряжок, вигнутих у перетині, які є характерними для пізньобабинської культури та зрідка трапляються в покровських комплексах. Надійно встановлене в курганах передування поховань ВДБК покровським і синхронність останніх пізньобабинській та пізньололінській культурам, встановлює верхню межу хронологічного діапазону волго-донських бабинських старожитностей не пізніше розвинених періодів ДДБК і Лоли, тобто до початку формування блоку колісничних культурних утворень [Мимоход 2013 , с. $172 ; 2014$, с. 115$]$.

При наявності двох етапів розвитку ВДБК, їх не вдається повноцінно наповнити комплексами, які б охопили основний масив пам'яток культури, як це, наприклад, зроблено для Дніпро-Донського Бабиного або Лоли. Достовірно до першого етапу можна віднести 30 поховань, 3 них кістки тварин знайдено в 20 могилах. До другого (заключного) періоду достовірно можна віднести лише чотири поховання, три з яких супроводжувалися кістками кінцівок ДРХ. Даних небагато, але деякі тенденції слід зазначити. У п'яти похованнях раннього етапу ВДБК КТ розміщено в нехарактерних для посткатакомбної традиції зонах: на віддалі від скелета, у черепа, за тазом (рис. 9: 1). Перші дві позиції більш характерні для катакомбних культур (рис. 8) [Мимоход 2007a, с. 122; рис. 4: 1-3; 2013a, с. 42, илл. 23: 1-3] ${ }^{10}$. КТ в цих зонах складають чверть від усіх поховань раннього етапу. Це суттєвий показник. У свою чергу, в достовірних похованнях другого (заключного) етапу ВДБК, в трьох 3 яких виявлено ноги ДРХ, всі вони перебували в одній 3 найпопулярніших зон - поблизу ліктьового суглоба лівої руки (рис. 9: 2). У зв'язку з цим можна обережно припустити, що розміщення КТ в нестандартних зонах, у більшості випадків катакомбних, може свідчити про

${ }^{10}$ У серії ранніх поховань ВДБК відомі поховання в катакомбах (7 комплексів), але жодного разу КТ не було виявлено у вхідних шахтах, що характерно для катакомбної обрядовості (рис. 8). 
ранні позиції подібних поховань, в тих випадках, коли інших даних для датування немає. Ситуація тут знову-таки знаходить структурні відповідності в лолінській культурі, періодизацію якої аргументовано краще, ніж для ВДБК. Саме в ранніх похованнях Лоли найкраще представлено катакомбні позиції розташування КТ [Мимоход 2007a, с. 123; рис. 4: 7; 2013a, с. 42, 43, илл. 23: 7].

Маркери господарської моделі. Картографування комплексів з КТ дозволяє зробити низку спостережень. Особливо показовим є поширення поховань 3 кістками ДРХ і ВРХ (рис. 1). Поховання з кістками вівці рівномірно представлено по всьому ареалу ВДБК, який охоплює зони південних пустельних, середніх сухих, північних степів та лісостеп. Примітно, що носії культури не стали освоювати зони північних пустель і широколистих лісів. Їх господарська скотарська модель була орієнтована винятково на степ і лісостеп. Втім, це стосується всього посткатакомбного блоку. Навіть найпівденніша його культура - лолінська - не просувається в зону північних пустель [Борисов, Мимоход 2017, рис. А], а з культурного кола Бабине на півдні широколистих лісів виявлено тільки периферійні та в культурному сенсі явно маргінальні групи: наддніпрянсько-прип'ятська, деснянська-сейменська та подільсько-волинська. Причому, тут представлено тільки поселення за відсутності могильників [Литвиненко 2008a; 2009, с. 11, 12; 2009a, с. 174-184, рис. 1; Отрощенко 2011, с. 160-161].

Поширення кісток тварин ВРX демонструє важливі закономірності. Як і ДРХ, ïх представлено по всьому ареалу культури (рис. 1). Однак питома вага за природними зонами змінюється в меридіональному напрямку 3 півдня на північ. Поховання 3 кістками ВРХ $€$ нечисельними в північній частині зони південних пустельних степів і на півдні середніх сухих степів, явно тяжіючи один до одного. Стабільно вони починають траплятися на межі середніх сухих та північних степів і добре представлені в останній зоні та лісостепу. Загалом у матеріалах ВДБК відомо 24 поховань 3 кістками ВРХ. У всіх виявлено ноги ВРХ (типи 2 і 3 ), тільки в одному комплексі - Висока Гора 5/1 - окремо від ноги (тип 2) лежали роги 3 верхньою частиною черепної коробки (тип 8) (рис. 4: 2). 3 них в південних пустельних степах виявлено 6 комплексів, що складають чверть від всіх поховань 3 кістками ВРХ; решта $75 \%$ поховань знаходяться в зоні північних середніх степів, на його південній межі та в лісостепу (рис. 1).

Повністю усвідомлюючи, що поховальний обряд доволі специфічно відбиває реалії, все-таки слід припустити, що виявлені закономірності в територіальному поширенні КТ відображають певні риси господарської моделі носіїв волго-донських бабинських традицій. Основу стада становила дрібна рогата худоба. Кістки вівці виявлено у 81,6\% поховань з КТ, а кістки ВРX - у 19,2\% ${ }^{11}$. У стаді велика рогата худоба була присутня, але вона посідала вторинну позицію відносно вівчарства ${ }^{12}$. Як уже зазначалося, кістки ВРХ траплялись на півдні ареалу ВДБК, але в значно меншій кількості, порівняно з рештою території. Це може бути пов'язано з більш аридним кліматом в південних пустельних та середніх сухих степах в порівнянні з північними степами і лесостепом. Ще більш очевидним це стане, якщо звернути увагу на два важливих факти.

На півдні ВДБК межує з лолінською культурою, основна територія якої знаходиться в Північно-західному Прикаспії та обіймає нішу південних пустельних степів (безлюдностепова зона) [Борисов, Мимоход 2017, рис. А]. Носії лолінських традицій спеціалізувалися винятково на вівчарстві ${ }^{13}$, що в умовах аридизації клімату було єдиним механізмом

${ }^{11}$ Такий показник питомої ваги (в сумі понад 100\%) зумовлено тим, що в деяких комплексах виявлено кістки ДРХ та ВРХ.

12 Достовірні кістки коня зафіксовано поки лише в одному комплексі ВДБК - Ріпний I 7/13 [Глебов 2004, с. 98]. Цей, самий південно-західний комплекс, знаходиться вже в ареалі ДДБК, у похованнях якої відомі кістки коня.

13 У похованнях лолінської культури трапляються лише кістки ДРХ [Мимоход 2007a]. Ïї поселення невідомі, і шанси їх виявлення невеликі. Добу бронзи в пустельно-степовій зоні, за 
виживання в такій сухій зоні, зумовленій кліматичними показниками не стільки в літній, скільки в зимовий період [Борисов и др. 2014, с. 283, 284; Борисов, Мимоход 2016, с. 10-12; 2017, с. 51-55; 2017a, с. 21-23; Борисов и др. 2018, с. 58-59; Мимоход 2019, с. 46-48]. Носії волго-донських бабинських традицій в південній частині свого ареалу використовували дуже близьку лолінській господарську модель скотарства, з тією різницею, що, будучи південною периферією свого культурного простору, їм, ймовірно, вдавалося утримувати нечисленну частину ВРХ в стаді та знаходити їй місце в сфері поховального обряду.

Цікаво відзначити другу закономірність. Кістки ВРХ в південному ареалі ВДБК відсутні в Заволжі, в той час як у цих природних зонах вони $є$ в волго-донському межиріччі (рис. 1). Волго-уральські степи, починаючи від лівого берега Волги, переходять в аридну зону, яка мало чим поступається степовим напівпустелям Північно-західного Прикаспію. Як наслідок, на ці терени носії катакомбних традицій проникали спорадично і їх не опанували [Ткачев 2006, с. 33; 2006a, с. 73; 2006б; 2007, с. 231]. У посткатакомбний період ВолгоУралля стало основною територією поширення волго-уральської культурної групи (ВУКГ), яка $\epsilon$ північним дериватом Лоли. Ії виникнення пов'язане 3 культурно-генетичними процесами в Передкавказзі [Мимоход 2010a; 2013a, с. 325, 326; 2018б]. Група нечисленна (43 поховання), але їі комплекси представлено у всьому регіоні [Мимоход 2018б, рис. 1]. Основу господарства тут також становить розведення ДРХ. Кістки тварин виявлено в 14 похованнях, 3 них кістки вівці містили 78,6\% поховань з КТ, великих копитних $-28,6 \%{ }^{14}$. Як видно, ситуація тут принципово схожа з ВДБК. Причому, кістки великої рогатої худоби та коней $\epsilon$ невідомими в зоні південних пустельних степів. Вони трапляються в прикордонній зоні середніх сухих і північних степів, а також в лісостепу, причому, безпосередньо на лівому березі Волги. В глибинних аридних волго-уральських степах у похованнях однойменної культурної групи відомо винятково кістки ДРХ. Іншими словами, на цій території ВУКГ, що $\epsilon$ північним дериватом лолінської культури, демонструє таку саме господарську модель, яка заснована на вівчарстві. Близькість природно-кліматичних умов аридних зон Північнозахідного Прикаспію та глибинних волго-уральських степів стала причиною того, що маргінальна частина населення лолінської культури на іï ранньому етапі мігрувала саме в порожнє Волго-Уралля (до звичної природно-кліматичної зони), зберігши найбільш ефективний (лолінський) метод адаптації в умовах аридних і напівпустельних степів.

Висновки. Кістки тварин у похованнях волго-донської бабинської культури (XXIIXVIII cal. BC) є надійним культурно-хронологічним індикатором. Її «візитівкою» виступають кістки ніг ДРХ, ВРХ та ДРХ/ВРХ. Розміщення їх у могилі було чітко стандартизованим. Як правило, вони лежать перед померлим поблизу лівої руки, найчастіше в районі кисті та ліктьового суглоба. На ранньому етапі ВДБК локалізація КТ в могилі демонструє риси генетичної спадкоємності 3 волго-донською катакомбною культурою. Кістки в деяких комплексах виявлено в нехарактерних для ВДБК зонах: на відстані від скелета та біля голови. Територіальне поширення поховань 3 кістками ДРХ і ВРХ дозволяє зробити висновки про господарську модель носіїв волго-донських бабинських традицій. Домінуючим у стаді була дрібна рогата худоба, бик/корова складали меншість. Виявляється стійка кореляція між долею поховань 3 кістками ДРХ і ВРХ та природно-кліматичними зонами. Кількість комплексів 3 кістками ВРХ істотно зростає від порубіжжя середніх сухих та північних степів і далі на північ, включаючи лісостеп. Швидше за все, це пов'язано з тим, що на цих територіях клімат був менш аридний, порівняно зі зонами середніх сухих і південних пустельних степів, що створювало умови для збільшення поголів'я великої рогатої худоби.

винятком фінального етапу, представлено курганними пам'ятками, що свідчить про рухомий характер скотарського укладу.

${ }^{14}$ Див. прим. 11. В матеріалах волго-уральської культурної групи серед комплексів 3 кістками великих копитних у двох випадках зафіксовано рештки ВРX, а ще в двох - коня. 


\section{КОСТИ ЖИВОТНЫХ В ВОЛГО-ДОНСКИХ БАБИНСКИХ ПОГРЕБЕНИЯХ КАК КУЛЬТУРНО-ХРОНОЛОГИЧЕСКИЕ ИНДИКАТОРЫ И МАРКЕРЫ ХОЗЯЙСТВЕННОЙ МОДЕЛИ}

Статья посвящена характеристике и анализу такого признака погребального обряда волгодонской бабинской культуры (XXII-XX cal. BC) как «кости животных». Их расположение в могиле и анатомический состав являются надежными культурно-хронологическими индикаторами. «Визитной карточкой» культуры является помещение в могилы костей конечностей МРС, КРС и МРС/КРС. Располагаются они, как правило, перед умершим у левой руки. Анализ количественного соотношения и территориального распространения погребений с костями МРС и КРС позволяет предварительно охарактеризовать хозяйственную модель носителей волго-донской бабинской культуры.

Ключевые слова: культурный круг Бабино, волго-донская бабинская культура, погребения, кости конечностей МРС и КРС, хронология, хозяйственная модель.

\section{R.A. Mimokhod}

\section{ANIMAL BONES AT THE VOLGA-DON BABYNE BURIALS AS CULTURAL-CHRONOLOGICAL INDICATORS AND MARKERS OF THE ECONOMIC MODEL}

The article is devoted to the characterization and analysis of such a sign of the funeral rite of the Volga-Don Babyne culture (XXII-XX cal. BC) as "animal bones". Their location in the grave and the anatomical composition are reliable cultural and chronological indicators. The "calling card" of the culture is the location of limbs bones of small cattle, cattle and small cattle/cattle in the graves. As a rule, they are located in front of a skeleton near a left hand. An analysis of the quantitative correlation and territorial distribution of burials with bones of small cattle and cattle allows us preliminarily to characterize the economic model of the carriers of the Volga-Don Babyne culture.

Keywords: Babyne Cultural Circle, Volga-Don Babyne culture, burials, limbs bones of small cattle and cattle, chronology, economic model.

\section{СПИСОК ДЖЕРЕЛ ТА ЛІТЕРАТУРИ}

Борисов А.В. Аридизация климата в пустынно-степной зоне: причины, формы проявления и влияние на жизнь древнего населения / [А.В. Борисов, М.В. Ельцов, С.Н. Удальцов, А.В. Бухонов] // Вестник ВолГУ. Серия 4: История. Религиоведение. Международные отношения. - Волгоград: ВолГУ, 2018. - Т. 23. - № 3. - С. 53-62.

Борисов А.В. Палеоэкология и палеоэкономика древних обществ пустынно-степной зоны в эпоху бронзы / А.В. Борисов, Р.А. Мимоход // Проблемы археологии Нижнего Поволжья, V Международная археологическая конференция (г. Элиста, 2016). - Элиста: Изд-во Калм. ун-та, 2016. - C. 9-13.

Борисов А.В. Аридизация: формы проявления и влияние на население степной зоны в бронзовом веке / А.В. Борисов, Р.А. Мимоход // РА. - 2017. - № 2. - С. 63-75.

Борисов А.В. Динамика природной среды и население пустынно-степной зоны в посткатакомбное и срубное время / А.В. Борисов, Р.А. Мимоход // Палеопочвы, палеоэкология, палеоэкономика. - Пущино, 2017а. - С. 20-25.

Борисов А.В. Теория оптимального кризиса, или Что кочевнику хорошо ... / А.В. Борисов, Р.А. Мимоход, В.А. Демкин // Сборник научно-популярных статей - победителей конкурса РФФИ 2013 года. - М.: МОЛНЕТ, 2014. - Вып. 17. - С. 278-286.

Гей А.Н. О некоторых символических моментах погребальной обрядности степных скотоводов Предкавказья в эпоху бронзы / А.Н. Гей // Погребальный обряд: реконструкция и интерпретация древних идеологических представлений. - М.: Издательская фирма «Восточная литература» РАН, 1995. - C. 78-113. 
Глебов В.П. Исследования курганных могильников Репный I, Раскатный I, Калинов II / В.П. Глебов // Труды Археологического научно-исследовательского бюро. - Т. І. - Ростов-н/Д, 2004. - C. 57-186.

Грищук О.М. Жінки у бабинському соціумі / О.М. Грищук // ДАЗ. - № 20. - Вінниця: Вид-во Донецьк. ун-ту, 2019.- С. 44-53.

Кияшко А.В. Погребения пришлых культур развитой и финальной средней бронзы в курганах Волго-Донского междуречья / А.В. Кияшко // Нижневолжский археологический вестник. Волгоград: Изд-во Волгоградского ун-та, 2003. - Вып. 6. - С. 26-36.

Кияшко А.В. Комплексы днепро-донской бабинской культуры в кургане 1 могильника Веселый I на Нижнем Дону / А.В. Кияшко, О.П. Ларенок // Археология и история Древнего Мира. Вып. VI. - Ростов-н/Д; Таганрог: Изд-во Южного федерального университета, 2019. - С. 3-7.

Ковалюх Н.Н. Новые радиоуглеродные даты посткатакомбных погребений Нижнего Поволжья и степного Предкавказья / Н.Н. Ковалюх, Р.А. Мимоход // Проблемы археологии Нижнего Поволжья: II Международная Нижневолжская археологическая конференция. - Волгоград: Изд-во ВолГУ, 2007. - C. 35-39.

Кореневский С.Н. Курганы позднего периода среднего бронзового века у станицы Архонская в Северной Осетии / С.Н. Кореневский, Р.А. Мимоход. - М.: Институт археологии РАН, 2011. - 120 с.

Косинцев П.А. Остатки животных из Калиновского могильника / П.А. Косинцев, Н.В. Рослякова // Охрана и изучение памятников истории и культуры в Самарской области. - Вып. 1. Самара, 1999. - С. 48-53.

Косинцев П.А. Останки животных из Калиновского могильника / П.А. Косинцев, Н.В. Рослякова // Калиновкий I курганный могильник. - Самара, 2006. - С. 79-83.

Кузнецов П.Ф. Грачевские курганы. Археология, антропология, геномный анализ / [П.Ф. Кузнецов, О.Д. Мочалов, А.А. Хохлов, Д.У. Энтони]. - Самара: СГСПУ, 2018. - 195 с.

Кузьмина О.В. Кости животных в погребальном обряде абашевской культуры / О.В. Кузьмина // Взаимодействие и развитие культур южного пограничья Европы и Азии: Материалы международной научной конференции, посвященной 100-летию со дня рождения И.В. Синицына (1900-1972), 14-18 мая 2000 года. - Саратов; Энгельс, 2000. - С. 59-66.

Литвиненко Р.А. Об одном типе посуды культуры многоваликовой керамики (КМК) / Р.А. Литвиненко // Матеріали археологічної конференції «Етнічна історія та культура населення степу та лісостепу Євразії (від кам'яного віку по раннє середньовіччя)» - Днепропетровск, 1999. - С. 83-86.

Литвиненко Р.А. Восточная периферия бабинского очага культурогенеза / Р.А. Литвиненко // Проблемы археологии Нижнего Поволжья: I Международная Нижневолжская археологическая конференция. - Волгоград: Изд-во ВолГУ, 2004. - С. 102-108.

Литвиненко Р.О. Культури бабинська та лолінська: до проблеми контактів / Р.О. Литвиненко // Проблеми дослідження пам’яток археології Східної України. - Луганськ, 2005. - С. 75-78.

Литвиненко Р.А. Опыт выявления пространственно-семиотических структур в погребальном обряде культуры Бабино / Р.А. Литвиненко // Структурно-семиотические исследования в археологии. - Т. 3. - Донецк: ДонНУ, 2006. - С. 215-236.

Литвиненко Р.А. Днепро-донская бабинская культура (источники, ареал, погребальный обряд) / Р.А. Литвиненко // МДАСУ. - № 5. - Луганськ: Вид-во СНУ ім. В. Даля, 2006а.- С. 157-187.

Литвиненко Р.О. Статево-вікова диференціація в поховальному обряді бабинських культур / Р.О. Литвиненко // МДАСУ. - № 7. - Луганськ: Вид-во СНУ ім. В. Даля, 2007. - С. 156-172.

Литвиненко Р.О. Пам'ятки типу Бабине III: від культури до культурного кола / Р.О. Литвиненко // Нові сторінки історії Донбасу. - Донецьк: Вид-во ДонНУ, 2008. - Кн. 15/16. - С. 342-354.

Литвиненко P.O. До оцінки периферійних груп Бабине полісько-лісостепової Наддніпрянщини / Р.О. Литвиненко // Вісник Донецького національного університету. Серія Б: гуманітарні науки. - Донецьк: Вид-во ДонНУ, 2008а. - № 2. - С. 180-190.

Литвиненко Р.О. Культурне коло Бабине (за матеріалами поховальних пам'яток): афтореф. дис. ... д-ра іст. наук: 07.00.04 - Археологія / Ін-т археол. НАНУ. - К., 2009. - 32 с.

Литвиненко Р.О. Культурне коло Бабине (за матеріалами поховальних пам'яток): дис. ... д-ра іст. наук: 07.00.04 / Ін-т археол. НАНУ. - К., 2009а. - 799 с. - НА ІА НАНУ. - Ф. 12. - Оп. 2. - № 879.

Литвиненко Р.О. Генеза, розвиток та історична доля культурного кола Бабине / Р.О. Литвиненко // МДАСУ. - № 9. - Луганськ: Вид-во СНУ ім. В. Даля, 2009б. - С. 44-89. 
Литвиненко Р.А. Культурный круг Бабино: название, таксономия, структура / Р.А. Литвиненко // КСИА. - Вып. 223. - М.: Наука, 2011.- С. 108-123.

Литвиненко Р.О.Бабинсько-криволуцьке порубіжжя / Р.О. Литвиненко // ДАЗ. - № 16. Донецьк: Вид-во Донецьк. ун-ту, 2012.- С. 47-76.

Литвиненко Р.О. Північне Приазов'я в системі східноєвропейського бронзового віку / P.О. Литвиненко // Україна и світ: проблеми історії: Збірник матеріалів Всеукраїнської науковопрактичної конференції. - Маріуполь: Вид-во МДУ, 2013. - С. 205-209.

Литвиненко Р.О. Поховання культурного кола Бабине 3 виробничим реманентом / P.О. Литвиненко// Наукові студії. . - Вип. 8: Давні майстерні та виробництво у Вісло-Дніпровському регіоні. - Винники; Жешів; Львів: Апріорі, 2015 - С. 113-136.

Литвиненко Р.О. Керамічний посуд в поховальній обрядовості бабинських культур / P.О. Литвиненко // Україна у світовому історичному просторі. Збірник матеріалів Всеукраїнської науково-практичної конференції. - Маріуполь: МДУ, 2016. - С. 209-213.

Литвиненко Р.О. Культурне коло Бабине: стан дослідженості й сучасні оцінки / P.О. Литвиненко // I Всеукраїнський археологічний з'їзд: Програма роботи та анотації доповідей (м. Ніжин, 23-25 листопада 2018 р.). - К: ІА НАНУ, 2018. - С. 90-91.

Литвиненко Р.А. Война в посткатакомбном мире / Р.А. Литвиненко // Stratum plus. - № 2. СПб; Кишинев; Одесса; Бухарест, 2019. - С. 313-382.

Литвиненко Р.А. Курган эпохи бронзы у села Запорожец (бассейн Кальмиуса, Северовосточное Приазовье) / Р.А. Литвиненко, Н.П. Зарайская // АА. - № 14. - Донецк, 2004. - С. 203-232.

Мамонтов В.И. Отчет о работе Приволжского отряда ЛОИА АН СССР, Волгоградского отделения ВООПИК и археологического отряда ВГПИ в 1979 г. - НА ИА РАН. - Р-1, №№ 7755, $7755 \mathrm{a}$.

Мимоход Р.А. О погребениях финала средней бронзы Северо-западного Прикаспия / Р.А. Мимоход // Чтения, посвященные 100-летию деятельности Василия Алексеевича Городцова в Государственном Историческом музее: тез. конф. - М., 2003. - Ч. І. - С. 103-107.

Мимоход Р. А. Погребения финала средней бронзы Нижнего Поволжья / Р.А. Мимоход // Проблемы археологии Нижнего Поволжья. I Международная Нижневолжская археологическая конференция: тез. докл. - Волгоград: Изд-во ВолГУ, 2004. - С. 108-114.

Мимоход Р.А. Блок посткатакомбных культурных образований (постановка проблемы) / Р.А. Мимоход // Проблеми дослідження пам’яток археології Східної України. - Луганськ: Шлях, 2005. - С. 70-74.

Мимоход Р.А. Погребения финала средней бронзы бассейна р. Кубань / Р.А. Мимоход // Первая абхазская международная археологическая конференция. Древние культуры Кавказского Причерноморья: материалы конференции. - Сухум, 2006. - С. 249-253.

Мимоход Р.А. Лолинская культура финала средней бронзы Северо-западного Прикаспия / Р.А. Мимоход // РА. - 2007. - № 4. - С. 143-154.

Мимоход Р.А. Кости животных в лолинских погребениях как культурно-хронологический индикатор / Р.А. Мимоход // МДАСУ. - № 7. - Луганськ: Вид-во СНУ ім. В. Даля, 2007а. - С. 118-127.

Мимоход P.A. Хронология криволукской культурной группы / Р.А. Мимоход // XVIII Уральское археологическое совещание. - Уфа: Изд-во БГПУ, 2010. - С. 158-160.

Мимоход Р.А. Погребения финала средней бронзы в Волго-Уралье и некоторые проблемы регионального культурогенеза / Р.А. Мимоход // ДАЗ. - 2009/2010. - №13/14. - Донецьк: Вид-во Донецьк. ун-ту, 2010а. - С. 67-82.

Мимоход Р.А. Посткатакомбный период в Нижнем Поволжье: содержание и дефиниции / Р.А. Мимоход // Археология восточно-европейской степи. - Вып. 10. - Саратов, 2013. - С. 167-179.

Мимоход Р.А. Лолинская культура. Северо-западный Прикаспий на рубеже среднего и позднего периодов бронзового века / Р.А. Мимоход // Материалы охранных археологических исследований. - Т. 16. - М.: ИА РАН, 2013а. - 568 с.

Мимоход Р.А. Посткатакомбный период в Восточной Европе: доклад на Международной конференции «Бронзовый век в Европе: актуальные исследования и перспективы» по случаю 10летия Представительства DFG в России и открытия выставки «Бронзовый век - Европа без границ» (г. Москва, 16.10.2013 г.). - М.: ГИМ, 2013б.

Мимоход Р.А. Посткатакомбный период в Нижнем Поволжье: от криволукской культурной группы к волго-донской бабинской культуре / Р.А. Мимоход // КСИА. - 2014. - Вып. 232. - С. 100-119. 
Мимоход Р.А. Блок посткатакомбных культурных образований в Восточной Европе: структура и содержание / Р.А. Мимоход // Изучение и сохранение археологического наследия народов Кавказа: XXIX Крупновские чтения. - Грозный: Изд-во Чеченского университета, 2016. - C. 45-47.

Мимоход Р.А. Посткатакомбный мир: концепция, структура, содержание / Р.А. Мимоход // V (XXI) Всероссийский археологический съезд [Электронный ресурс]: сборник научных трудов / отв. ред. А.П. Деревянко, А.А. Тишкин. - Барнаул: ФГБОУ ВО «Алтайский государственный университет», 2017. - С. 695-696.

Мимоход Р.А. Палеоклимат и культурогенез в Восточной Европе в конце III тыс. до н.э. / Р.А. Мимоход // РА. - 2018 - № 2. - С. 33-48.

Мимоход Р.А. Стратифицированные курганы бронзового века на правобережье Северского Донца / Р.А. Мимоход // Материалы спасательных археологических исследований. - М.: ИА РАН, 2018a. - Т. 23. -288 c.

Мимоход Р.А. Посткатакомбный период в Волго-Уральском регионе / Р.А. Мимоход // XXI Уральское археологическое совещание, посвященное 85-летию со дня рождения Г.И. Матвеевой и 70-летию со дня рождения И.Б. Васильева. - Самара: Изд-во СГСПУ; ООО «Порто-принт», 2018б. - С. 140-144.

Мимоход Р.А. Теория оптимального кризиса: экология и адаптация / Р.А. Мимоход // Природа. - 2019. - № 1. - С. 43-49.

Моргунова Н.Л. Скворцовский курганный могильник / [Н.Л. Моргунова, А.А. Гольева, А.Д. Дегтярева, А.А. Евгеньев, Л.В. Купцова, Н.П. Салугина, .С. Хохлова, А.А. Хохлов]. Оренбург: Издательство ОГПУ, 2010. - 160 с.

Отрощенко В.В. Проблеми вивчення пам'яток бабинської спільноти Середньої Наддніпрянщини / В.В. Отрощенко // Переяславіка. Наукові записки Національного історикоетнографічного заповідника «Переяслав». - Вип. 5 (7). - Переяслав-Хмельницький, 2011. - С. 159-162.

Писларий И.А. Погребальный обряд племен культуры многоваликовой керамики / И.А. Писларий // Древняя история населения Украины. - К., 1991. - С. 52-66.

Скворцов Н.Б. Отчет о раскопках в Николаевском районе Волгоградской области в 1999 г. Фонды Волгоградского областного краеведческого музея. - №№ 950606, 960114, 960509.

Ткачев В.В. Заключительный этап эпохи средней бронзы в степном Приуралье / В.В. Ткачев. Челябинск: Рифей, 2006. - 75 с.

Ткачев В.В. Степное Приуралье на рубеже эпох средней и поздней бронзы / В.В. Ткачев. Челябинск: Рифей, 2006а. - 137 с.

Ткачев В.В. Культурная принадлежность памятников конца среднего бронзового века в степном Приуралье / В.В. Ткачев // Проблемы изучения ямной культурно-исторической области. Оренбург: Изд-во ОГПУ, 2006б. - С. 88-94.

Ткачев В.В. Степи Южного Приуралья и Западного Казахстана на рубеже эпох средней и поздней бронзы / В.В. Ткачев. - Актобе: Актюбинский областной центр истории, этнографии и археологии, 2007. - $384 \mathrm{c}$.

Шарафутдинова Э.С. О культурных группах погребений конца эпохи средней - начала поздней бронзы Степного Поволжья / Э.С. Шарафутдинова // Комплексные общества Центральные Евразии в III-I тыс. до н.э. Региональные особенности в свете универсальных моделей: материалы к международной конференции (25 августа - 2 сентября 1999 г.). - Челябинск; Аркаим, 1999. - С. 159-163.

Шарафутдинова Э.С. К вопросу о погребальных памятниках конца эпохи средней бронзы в Нижнем Поволжье / Э.С. Шарафутдинова // Бронзовый век Восточной Европы: характеристика культур, хронология и периодизация: материалы международной научной конференции «К столетию периодизации В.А. Городцова бронзового века южной половины Восточной Европы» (23-28 апреля 2001 г.). - Самара: Изд-во ООО «НТЦ», 2001. - С. 148-153.

Черных Е.Н. Радиоуглеродная хронология катакомбной культурно-исторической общности (средний бронзовый век) / Е.Н. Черных, Л.Б. Орловская // РА. - 2004. - № 2. - С. 15-29.

\section{REFERENCES}

Borisov A.V. Aridizaciya klimata v pustynno-stepnoj zone: prichiny, formy proyavleniya i vliyanie na zhizn' drevnego naseleniya / [A.V. Borisov, M.V. El'cov, S.N. Udal'cov, A.V. Buhonov] // Vestnik VolGU. Seriya 4: Istoriya. Religiovedenie. Mezhdunarodnye otnosheniya. - Volgograd: VolGU, 2018. - T. 23. - № 3. - S. 53-62. 
Borisov A.V. Paleoekologiya i paleoekonomika drevnih obshchestv pustynno-stepnoj zony v epohu bronzy / A.V. Borisov, R.A. Mimohod // Problemy arheologii Nizhnego Povolzh'ya, V Mezhdunarodnaya arheologicheskaya konferenciya (g. Elista, 2016). - Elista: Izd-vo Kalm. un-ta, 2016. - S. 9-13.

Borisov A.V. Aridizaciya: formy proyavleniya i vliyanie na naselenie stepnoj zony v bronzovom veke / A.V. Borisov, R.A. Mimohod // RA. - 2017. - № 2. - S. 63-75.

Borisov A.V. Dinamika prirodnoj sredy i naselenie pustynno-stepnoj zony v postkatakombnoe i srubnoe vremya / A.V. Borisov, R.A. Mimohod // Paleopochvy, paleoekologiya, paleoekonomika. Pushchino, 2017a. - S. 20-25.

Borisov A.V. Teoriya optimal'nogo krizisa, ili CHto kochevniku horosho ... / A.V. Borisov, R.A. Mimohod, V.A. Demkin // Sbornik nauchno-populyarnyh statej - pobeditelej konkursa RFFI 2013 goda. M.: MOLNET, 2014. - Vyp. 17. - S. 278-286.

Gej A.N. O nekotoryh simvolicheskih momentah pogrebal'noj obryadnosti stepnyh skotovodov Predkavkaz'ya v epohu bronzy / A.N. Gej // Pogrebal'nyj obryad: rekonstrukciya i interpretaciya drevnih ideologicheskih predstavlenij. - M.: Izdatel'skaya firma «Vostochnaya literatura» RAN, 1995. - S. 78-113.

Glebov V.P. Issledovaniya kurgannyh mogil'nikov Repnyj I, Raskatnyj I, Kalinov II / V.P. Glebov // Trudy Arheologicheskogo nauchno-issledovatel'skogo byuro. - T. I. - Rostov-n/D, 2004. - S. 57-186.

Hryshchuk O.M. Zhinky u babynskomu sotsiumi / O.M. Hryshchuk // DAZ. - № 20. - Vinnytsia: Vyd-vo Donetsk. un-tu, 2019.- S. 44-53.

Kiyashko A.V. Pogrebeniya prishlyih kultur razvitoy i finalnoy sredney bronzyi v kurganah VolgoDonskogo mezhdurechya / A.V. Kiyashko // Nizhnevolzhskiy arheologicheskiy vestnik. - Volgograd: Izd-vo Volgogradskogo un-ta, 2003. - Vyp. 6. - S. 26-36.

Kiyashko A.V. Kompleksyi dnepro-donskoy babinskoy kulturyi v kurgane 1 mogilnika Veselyiy I na Nizhnem Donu / A.V. Kiyashko, O.P. Larenok // Arheologiya i istoriya Drevnego Mira. - Vyp. VI. Rostov-n/D; Taganrog: Izd-vo Yuzhnogo federalnogo universiteta, 2019. - S. 3-7.

Kovalyuh N.N. Novyie radiouglerodnyie datyi postkatakombnyih pogrebeniy Nizhnego Povolzhya i stepnogo Predkavkazya / N.N. Kovalyuh, R.A. Mimohod // Problemyi arheologii Nizhnego Povolzhya: II Mezhdunarodnaya Nizhnevolzhskaya arheologicheskaya konferentsiya. - Volgograd: Izd-vo VolGU, 2007. - S. 35-39.

Korenevskiy S.N. Kurganyi pozdnego perioda srednego bronzovogo veka u stanitsyi Arhonskaya v Severnoy Osetii / S.N. Korenevskiy, R.A. Mimohod. - M.: Institut arheologii RAN, 2011. - 120 s.

Kosintsev P.A. Ostatki zhivotnyih iz Kalinovskogo mogilnika / P.A. Kosintsev, N.V. Roslyakova // Ohrana i izuchenie pamyatnikov istorii i kulturyi v Samarskoy oblasti. - Vyp. 1. - Samara, 1999. - S. 48-53.

Kosintsev P.A. Ostanki zhivotnyih iz Kalinovskogo mogilnika / P.A. Kosintsev, N.V. Roslyakova // Kalinovkiy I kurgannyiy mogilnik. - Samara, 2006. - S. 79-83.

Kuznetsov P.F. Grachevskie kurganyi. Arheologiya, antropologiya, genomnyiy analiz / [P.F. Kuznetsov, O.D. Mochalov, A.A. Hohlov, D.U. Entoni]. - Samara: SGSPU, 2018. - 195 s.

Kuzmina O.V. Kosti zhivotnyih v pogrebalnom obryade abashevskoy kulturyi / O.V. Kuzmina // Vzaimodeystvie i razvitie kultur yuzhnogo pogranichya Evropyi i Azii: Materialyi mezhdunarodnoy nauchnoy konferentsii, posvyaschennoy 100-letiyu so dnya rozhdeniya I.V. Sinitsyina (1900-1972), 14-18 maya 2000 goda. - Saratov; Engels, 2000. - S. 59-66.

Litvinenko R.A. Ob odnom tipe posudyi kulturyi mnogovalikovoy keramiki (KMK) / R.A. Litvinenko // Materialy arkheolohichnoi konferentsii «Etnichna istoriia ta kultura naselennia stepu ta lisostepu Yevrazii (vid kam'ianoho viku po rannie serednovichchia)» - Dnepropetrovsk, 1999. - S. 83-86.

Litvinenko R.A. Vostochnaya periferiya babinskogo ochaga kulturogeneza / R.A. Litvinenko // Problemyi arheologii Nizhnego Povolzhya: I Mezhdunarodnaya Nizhnevolzhskaya arheologicheskaya konferentsiya. - Volgograd: Izd-vo VolGU, 2004. - S. 102-108.

Lytvynenko R.O. Kultury babynska ta lolinska: do problemy kontaktiv / R.O. Lytvynenko // Problemy doslidzhennia pam'iatok arkheolohii Skhidnoi Ukrainy. - Luhansk, 2005. - S. 75-78.

Litvinenko R.A. Opyit vyiyavleniya prostranstvenno-semioticheskih struktur v pogrebalnom obryade kulturyi Babino / R.A. Litvinenko // Strukturno-semioticheskie issledovaniya v arheologii. - T. 3. - Donetsk: DonNU, 2006. - S. 215-236.

Litvinenko R.A. Dnepro-donskaya babinskaya kultura (istochniki, areal, pogrebalnyiy obryad) /

R.A. Litvinenko // MDASU. - № 5. - Luhansk: Vyd-vo SNU im. V. Dalia, 2006a.- S. 157-187.

Lytvynenko R.O. Statevo-vikova dyferentsiatsiia v pokhovalnomu obriadi babynskykh kultur / R.O.

Lytvynenko // MDASU. - № 7. - Luhansk: Vyd-vo SNU im. V. Dalia, 2007. - S. 156-172. 
Lytvynenko R.O. Pam'iatky typu Babyne III: vid kultury do kulturnoho kola / R.O. Lytvynenko // Novi storinky istorii Donbasu. - Donetsk: Vyd-vo DonNU, 2008. - Kn. 15/16. - S. 342-354.

Lytvynenko R.O. Do otsinky peryferiinykh hrup Babyne polisko-lisostepovoi Naddniprianshchyny / R.O. Lytvynenko // Visnyk Donetskoho natsionalnoho universytetu. Seriia B: humanitarni nauky. - Donetsk: Vyd-vo DonNU, 2008a. - № 2. - S. 180-190.

Lytvynenko R.O. Kulturne kolo Babyne (za materialamy pokhovalnykh pam'iatok): aftoref. dys. ... d-ra ist. nauk: 07.00.04 - Arkheolohiia / In-t arkheol. NANU. - K., 2009. - 32 s.

Lytvynenko R.O. Kulturne kolo Babyne (za materialamy pokhovalnykh pam'iatok): dys. ... d-ra ist. nauk: 07.00.04 / In-t arkheol. NANU. - K., 2009a. - 799 s. - NA IA NANU. - F. 12. - Op. 2. - № 879.

Lytvynenko R.O. Heneza, rozvytok ta istorychna dolia kulturnoho kola Babyne / R.O. Lytvynenko // MDASU. - № 9. - Luhansk: Vyd-vo SNU im. V. Dalia, 2009b. - S. 44-89.

Litvinenko R.A. Kulturnyiy krug Babino: nazvanie, taksonomiya, struktura / R.A. Litvinenko // KSIA. - Vyp. 223. - M.: Nauka, 2011.- S. 108-123.

Lytvynenko R.O. Babynsko-kryvolutske porubizhzhia / R.O. Lytvynenko // DAZ. - № 16. Donetsk: Vyd-vo Donetsk. un-tu, 2012.- S. 47-76.

Lytvynenko R.O. Pivnichne Pryazov'ia v systemi skhidnoievropeiskoho bronzovoho viku / R.O. Lytvynenko // Ukraina y svit: problemy istorii: Zbirnyk materialiv Vseukrainskoi naukovo-praktychnoi konferentsii. - Mariupol: Vyd-vo MDU, 2013. - S. 205-209.

Lytvynenko R.O. Pokhovannia kulturnoho kola Babyne z vyrobnychym remanentom / R.O. Lytvynenko// Naukovi studii. . - Vyp. 8: Davni maisterni ta vyrobnytstvo u Vislo-Dniprovskomu rehioni. Vynnyky; Zheshiv; Lviv: Apriori, 2015 - S. 113-136.

Lytvynenko R.O. Keramichnyi posud $\mathrm{v}$ pokhovalnii obriadovosti babynskykh kultur / R.O. Lytvynenko // Ukraina u svitovomu istorychnomu prostori. Zbirnyk materialiv Vseukrainskoi naukovopraktychnoi konferentsii. - Mariupol: MDU, 2016. - S. 209-213.

Lytvynenko R.O. Kulturne kolo Babyne: stan doslidzhenosti y suchasni otsinky / R.O. Lytvynenko // I Vseukrainskyi arkheolohichnyi z’izd: Prohrama roboty ta anotatsii dopovidei (m. Nizhyn, 23-25 lystopada 2018 r.). - K: IA NANU, 2018. - S. 90-91.

Litvinenko R.A. Voyna v postkatakombnom mire / R.A. Litvinenko // Stratum plus. - № 2. - SPb; Kishinev; Odessa; Buharest, 2019. - S. 313-382.

Litvinenko R.A. Kurgan epohi bronzyi u sela Zaporozhets (basseyn Kalmiusa, Severo-vostochnoe Priazove) / R.A. Litvinenko, N.P. Zarayskaya // AA. - № 14. - Donetsk, 2004 . - S. 203-232.

Mamontov V.I. Otchet o rabote Privolzhskogo otryada LOIA AN SSSR, Volgogradskogo otdeleniya VOOPIK i arheologicheskogo otryada VGPI v 1979 g. - NA IA RAN. - R-1, № 7755, 7755a.

Mimohod R.A. O pogrebeniyah finala sredney bronzyi Severo-zapadnogo Prikaspiya / R.A. Mimohod // Chteniya, posvyaschennyie 100-letiyu deyatelnosti Vasiliya Alekseevicha Gorodtsova v Gosudarstvennom Istoricheskom muzee: tez. konf. - M., 2003. - Ch. I. - S. 103-107.

Mimohod R.A. Pogrebeniya finala sredney bronzyi Nizhnego Povolzhya / R.A. Mimohod // Problemyi arheologii Nizhnego Povolzhya. I Mezhdunarodnaya Nizhnevolzhskaya arheologicheskaya konferentsiya: tez. dokl. - Volgograd: Izd-vo VolGU, 2004. - S. 108-114.

Mimohod R.A. Blok postkatakombnyih kulturnyih obrazovaniy (postanovka problemyi) / R.A. Mimohod // Problemy doslidzhennia pam'iatok arkheolohii Skhidnoi Ukrainy. - Luhansk: Shliakh, 2005. - S. 70-74.

Mimohod R.A. Pogrebeniya finala sredney bronzyi basseyna r. Kuban / R.A. Mimohod // Pervaya abhazskaya mezhdunarodnaya arheologicheskaya konferentsiya. Drevnie kulturyi Kavkazskogo Prichernomorya: materialyi konferentsii. - Suhum, 2006. - S. 249-253.

Mimohod R.A. Lolinskaya kultura finala sredney bronzyi Severo-zapadnogo Prikaspiya / R.A. Mimohod // RA. - 2007. - № 4. - S. 143-154.

Mimohod R.A. Kosti zhivotnyih v lolinskih pogrebeniyah kak kulturno-hronologicheskiy indikator / R.A. Mimohod // MDASU. - № 7. - Luhansk: Vyd-vo SNU im. V. Dalia, 2007a. - S. 118-127.

Mimohod R.A. Hronologiya krivolukskoy kulturnoy gruppyi / R.A. Mimohod // XVIII Uralskoe arheologicheskoe soveschanie. - Ufa: Izd-vo BGPU, 2010. - S. 158-160.

Mimohod R.A. Pogrebeniya finala sredney bronzyi v Volgo-Urale i nekotoryie problemyi regionalnogo kulturogeneza / R.A. Mimohod // DAZ. - 2009/2010. - №13/14. - Donetsk: Vyd-vo Donetsk. un-tu, 2010a. - S. 67-82.

Mimohod R.A. Postkatakombnyiy period v Nizhnem Povolzhe: soderzhanie i definitsii / R.A. Mimohod // Arheologiya vostochno-evropeyskoy stepi. - Vyp. 10. - Saratov, 2013. - S. 167-179. 
Mimohod R.A. Lolinskaya kultura. Severo-zapadnyiy Prikaspiy na rubezhe srednego i pozdnego periodov bronzovogo veka / R.A. Mimohod // Materialyi ohrannyih arheologicheskih issledovaniy. - T. 16. M.: IA RAN, 2013a. - 568 s.

Mimohod R.A. Postkatakombnyiy period v Vostochnoy Evrope: doklad na Mezhdunarodnoy konferentsii «Bronzovyiy vek v Evrope: aktualnyie issledovaniya i perspektivyi» po sluchayu 10-letiya Predstavitelstva DFG v Rossii i otkryitiya vyistavki «Bronzovyiy vek - Evropa bez granits» (g. Moskva, 16.10.2013 g.). - M.: GIM, 2013b.

Mimohod R.A. Postkatakombnyiy period v Nizhnem Povolzhe: ot krivolukskoy kulturnoy gruppyi k volgo-donskoy babinskoy kulture / R.A. Mimohod // KSIA. - 2014. - Vyp. 232. - S. 100-119.

Mimohod R.A. Blok postkatakombnyih kulturnyih obrazovaniy v Vostochnoy Evrope: struktura i soderzhanie / R.A. Mimohod // Izuchenie i sohranenie arheologicheskogo naslediya narodov Kavkaza: XXIX Krupnovskie chteniya. - Groznyiy: Izd-vo Chechenskogo universiteta, 2016. - S. 45-47.

Mimohod R.A. Postkatakombnyiy mir: kontseptsiya, struktura, soderzhanie / R.A. Mimohod // V (XXI) Vserossiyskiy arheologicheskiy s'ezd [Elektronnyiy resurs]: sbornik nauchnyih trudov / otv. red. A.P. Derevyanko, A.A. Tishkin. - Barnaul: FGBOU VO «Altayskiy gosudarstvennyiy universitet», 2017. S. 695-696.

Mimohod R.A. Paleoklimat i kulturogenez v Vostochnoy Evrope v kontse III tyis. do n.e. / R.A. Mimohod // RA. - 2018 - № 2. - S. 33-48.

Mimohod R.A. Stratifitsirovannyie kurganyi bronzovogo veka na pravoberezhe Severskogo Dontsa / R.A. Mimohod // Materialyi spasatelnyih arheologicheskih issledovaniy. - M.: IA RAN, 2018a. - T. 23. - 288 s.

Mimohod R.A. Postkatakombnyiy period v Volgo-Uralskom regione / R.A. Mimohod // XXI Uralskoe arheologicheskoe soveschanie, posvyaschennoe 85-letiyu so dnya rozhdeniya G.I. Matveevoy i 70letiyu so dnya rozhdeniya I.B. Vasileva. - Samara: Izd-vo SGSPU; OOO «Porto-print», 2018b. - S. 140-144.

Mimohod R.A. Teoriya optimalnogo krizisa: ekologiya i adaptatsiya / R.A. Mimohod // Priroda. 2019. - № 1. - S. 43-49.

Morgunova N.L. Skvortsovskiy kurgannyiy mogilnik / [N.L. Morgunova, A.A. Goleva, A.D. Degtyareva, A.A. Evgenev, L.V. Kuptsova, N.P. Salugina, O.S. Hohlova, A.A. Hohlov]. - Orenburg: Izdatelstvo OGPU, 2010. - $160 \mathrm{~s}$.

Otroshchenko V.V. Problemy vyvchennia pam'iatok babynskoi spilnoty Serednoi Naddniprianshchyny / V.V. Otroshchenko // Pereiaslavika. Naukovi zapysky Natsionalnoho istorykoetnohrafichnoho zapovidnyka «Pereiaslav». - Vyp. 5 (7). - Pereiaslav-Khmelnytskyi, 2011. - S. 159-162.

Pislariy I.A. Pogrebalnyiy obryad plemen kulturyi mnogovalikovoy keramiki / I.A. Pislariy // Drevnyaya istoriya naseleniya Ukrainyi. - K., 1991. - S. 52-66.

Skvortsov N.B. Otchet o raskopkah v Nikolaevskom rayone Volgogradskoy oblasti v 1999 g. Fondyi Volgogradskogo oblastnogo kraevedcheskogo muzeya. - № 950606, 960114, 960509.

Tkachev V.V. Zaklyuchitelnyiy etap epohi sredney bronzyi v stepnom Priurale / V.V. Tkachev. Chelyabinsk: Rifey, 2006. -75 s.

Tkachev V.V. Stepnoe Priurale na rubezhe epoh sredney i pozdney bronzyi / V.V. Tkachev. Chelyabinsk: Rifey, 2006a. - 137 s.

Tkachev V.V. Kulturnaya prinadlezhnost pamyatnikov kontsa srednego bronzovogo veka v stepnom Priurale / V.V. Tkachev // Problemyi izucheniya yamnoy kulturno-istoricheskoy oblasti. - Orenburg: Izd-vo OGPU, 2006b. - S. 88-94.

Tkachev V.V. Stepi Yuzhnogo Priuralya i Zapadnogo Kazahstana na rubezhe epoh sredney i pozdney bronzyi / V.V. Tkachev. - Aktobe: Aktyubinskiy oblastnoy tsentr istorii, etnografii i arheologii, 2007. - $384 \mathrm{~s}$.

Sharafutdinova E.S. O kulturnyih gruppah pogrebeniy kontsa epohi sredney - nachala pozdney bronzyi Stepnogo Povolzhya / E.S. Sharafutdinova // Kompleksnyie obschestva Tsentralnyie Evrazii v III-I tyis. do n.e. Regionalnyie osobennosti $\mathrm{v}$ svete universalnyih modeley: materialyi $\mathrm{k}$ mezhdunarodnoy konferentsii (25 avgusta - 2 sentyabrya 1999 g.). - Chelyabinsk; Arkaim, 1999. - S. 159-163.

Sharafutdinova E.S. K voprosu o pogrebalnyih pamyatnikah kontsa epohi sredney bronzyi v Nizhnem Povolzhe / E.S. Sharafutdinova // Bronzovyiy vek Vostochnoy Evropyi: harakteristika kultur, hronologiya i periodizatsiya: materialyi mezhdunarodnoy nauchnoy konferentsii «K stoletiyu periodizatsii V.A. Gorodtsova bronzovogo veka yuzhnoy polovinyi Vostochnoy Evropyi» (23-28 aprelya 2001 g.). Samara: Izd-vo OOO «NTTs», 2001. - S. 148-153.

Chernyih E.N. Radiouglerodnaya hronologiya katakombnoy kulturno-istoricheskoy obschnosti (sredniy bronzovyiy vek) / E.N. Chernyih, L.B. Orlovskaya // RA. - 2004. - № 2. - S. 15-29. 


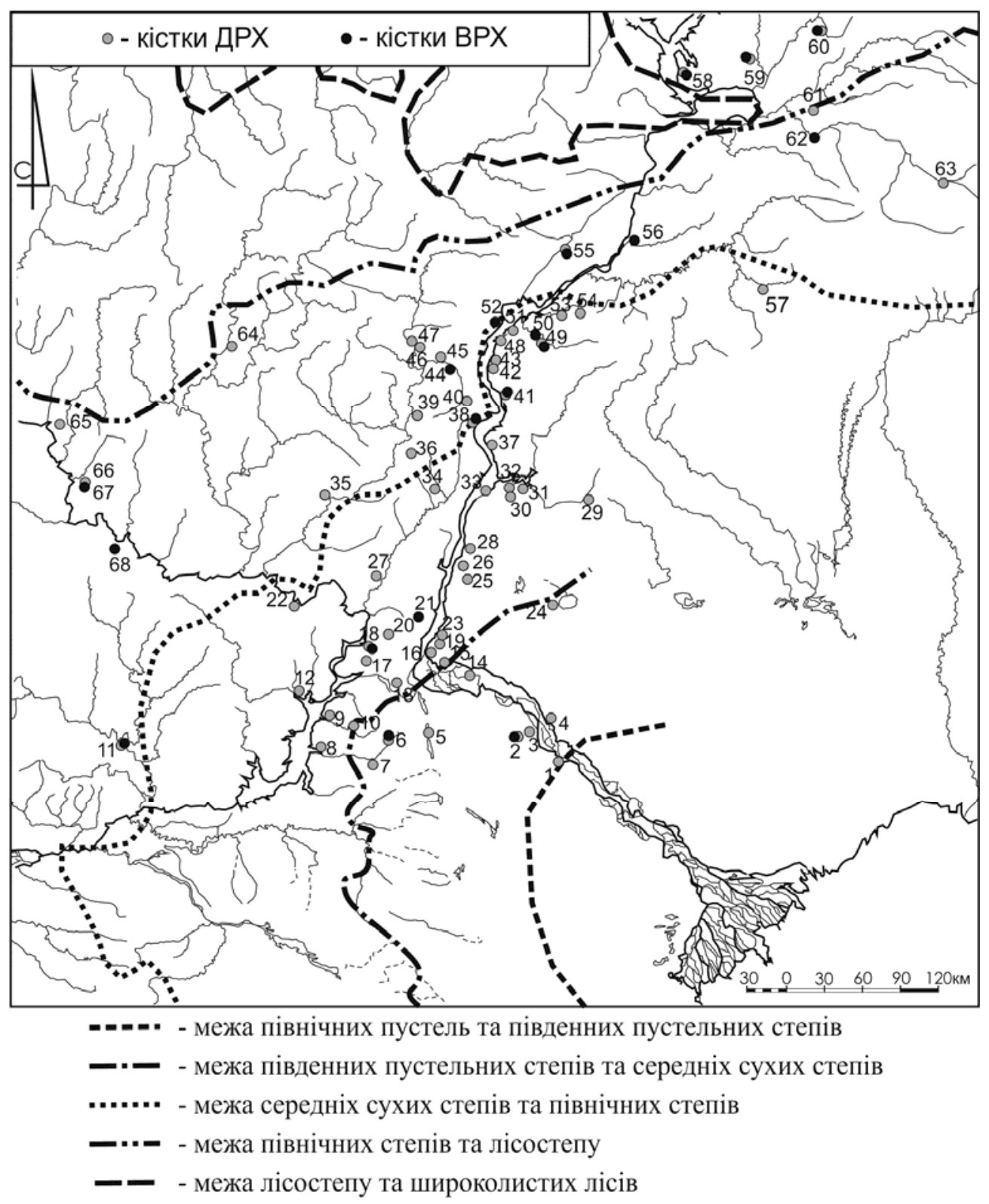

Рис. 1. Карта поховань з кістками ДРХ та ВРХ в контексті природно-кліматичного зонування: 1 - Нікольське I 1/5,9; 2 - Крива Лука X 1/9, XI 4/5, XIV 15/10, XV 2/12, XXI 2/4, XXIII 1/8, 3/3, XXXIII 4/2, XXXIV 2/2, 5/4,7; 3 - Баранівка 2/4; 4 - Степова IV 3/1; 5 - Цаца 1/4; 6 - Абганерове III 12/9; 7 - Аксай I 15/17; 8 - Ромашкін II 1/11; 9 - Первомайський I 8/5; 10 - Громославка II 2/8; 11 Ріпний I 7/13, 17; 12 - Чир II 2/1; 13 - Орошаємий 1 4/3; 14 - Царів 66/1; 15 - х. Степана Разіна 1/14; 16 - Волзький 2/11,16; 17 - Дмитрівка 9/5; 18 - Вертячий 7/7, 15, 24, 25; 19 - Калинівський 6/1, 8/15, 54/2; 20 - Котлубань I 7/2, II 4/2; 21 - Усть-Погоже 1/2; 22 - Свстратівський II 4/3; 23 - Верхнє Погромне 3/8; 24 - Красна дєрєвня 8/4, 15/5; 25 - Ямки 1/4, 3/8; 26 - Верхній Баликлей 4/3,4, 6/6; 27 Писарівка II 10/2; 28 - Бикове I 4/3,11, 6/2, 22/2, II 5/9; 29 - Кумиска II 1/2; 30 - Нова Молчанівка 1/7; 31 - Західні могили 20/5; 32 - Бережнівка I 4/3, 5/8,21, 8/5, II 3/5, 9/14, 14/14, 87/3; 33 Політодєльське $3 / 5,4 / 27 ; 34$ - Авіловський 20/6; 35 - Сидори 26/1; 36 - Бурлук I 1/2; 37 Білокам'янка $3 / 8 ; 38$ - Білогірське I ск.1/1,7,14,15; 39 - Линьове 6/6, 8/2; 40 - Красноармійське $1 / 6,7$; 41 - Скатівка 6/1, 18/1, 27/1; 42 - Узморье 1/6; 43 - Смілівка 2/1; Смілівка, гр. мог. п. 111; 44 Рибушка 15/2; 45 - Велика Дмитрівка II 1/6; 46 - Широкий Карамиш 4/10; 47 - Симонівка 1/1; 48 Сусловський 9/1; 49 - Совєтське 2/15, один. курган/6; 50 - Крутоярівка $11 / 3 ; \mathbf{5 1}$ - Покровськ 36/1, Покровський курган п. 1; 52 - Усть-Курдюм 6/1; 53 - Рунталь 1/1; 54 - Калмицька Гора F 6/7, 2/10, Бородаївка 2/3; 55 - Дмитрівка 1/1, 2/1; 56 - Калач, гр. мог. р. 2 п. 1; 57 - Світле Озеро 6/3; 58 Ягідне I 3/1; 59 - Миколаївка 3 2/1, 3/3, 4/1; 60 - Калинівський I 1/4; 61 - Грачовка I 1/1, II 10/1; 62 Утьовка V 4/1; 63 - Скворцовка 5/3 скелет 1; 64 - Власівський I 7/1, 14/1; 65 - Липовка 1 5/1; 66 Павлівськ II ск. 2/38; 67 - Павлівський 41/3; 68 - Висока Гора 5/1

Fig. 1. The distribution of WDBC burials with cattle and small cattle bones in the context of natural-climatic zoning 


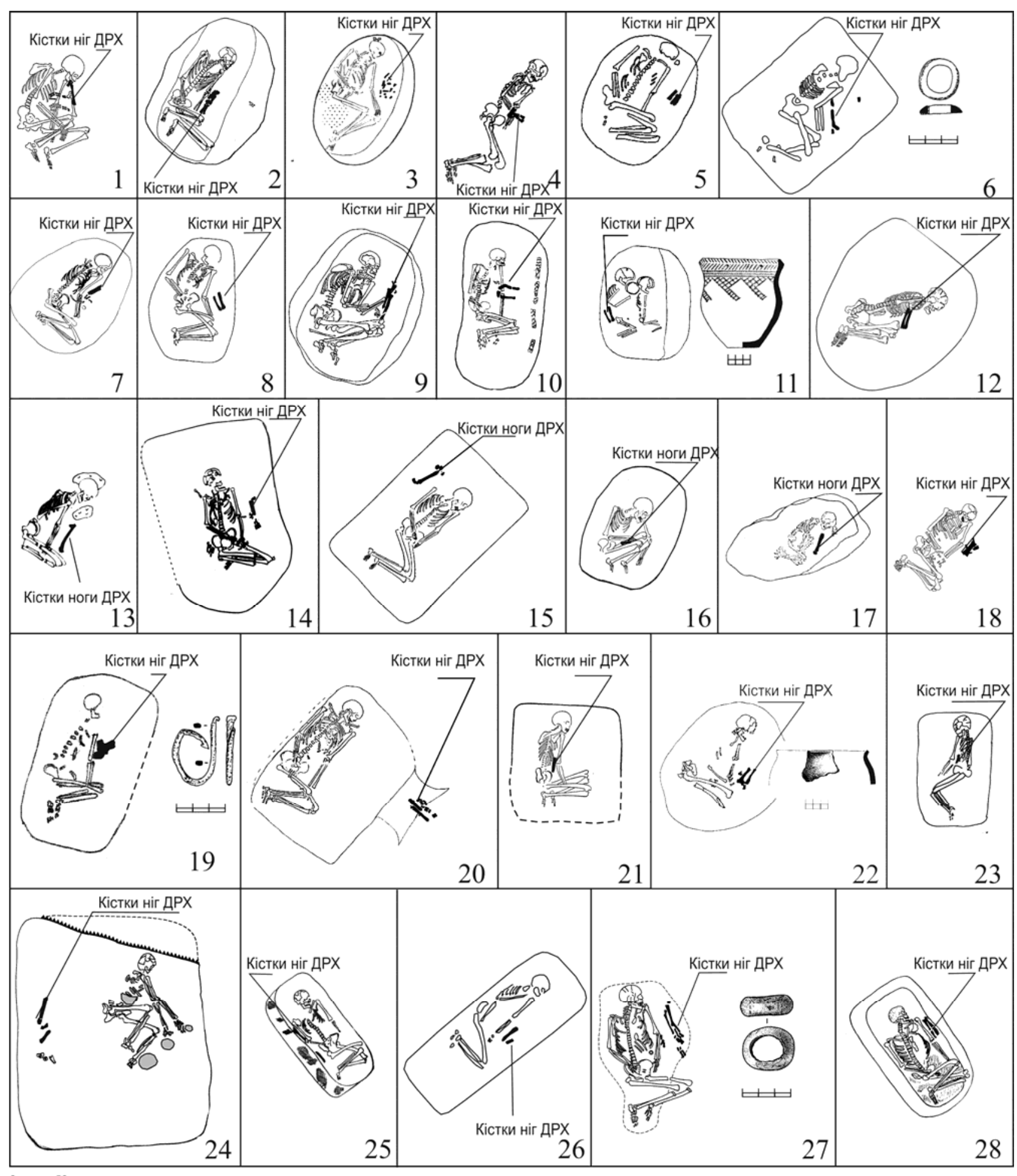

$\stackrel{50 \mathrm{~cm}}{\uplus \pm \uplus}-$ масштаб до планів поховань

Рис. 2. Поховання з КТ типу 1 (кістки ніг/ноги ДРХ):

1 - Бережнівка I 5/8; 2 - Громославка II 2/8; 3 - Політодєльське 3/5; 4 - Грачівка I 1/1; 5 - Верхній Баликлей 6/6; 6 - Власівський I 7/1; 7 - Крива Лука XXXIII 4/2; 8 - Нікольське I 1/9; 9 Красноармійське 1/7; 10 - Котлубань II 4/2; 11 - Білогірське I ск.1/15; 12 - Грачівка II 10/1; 13 Волзький 2/16; 14 - Чир II 2/1; 15 - Бережнівка II 3/5; 16 - Бережнівка II 87/3; 17 - Калинівський 6/1; 18 - Скворцовка 5/3; 19 - Красна дєрєвня 15/5; 20 - Кумиска II 1/2; 21 - Скатівка 18/1; 22 Калмицька Гора-1982 2/10; 23 - Красна дєрєвня 8/4; 24 - Калмицька Гора-2012 п. 6; 25 - Орошаємий I 4/3; 26 - Білогорське I ск.1/1; 27 - Свстратівський II 4/3; 28 - Ромашкін II окр. кург/6

Fig. 2. Burial with animal bones of type 1 (small cattle bones of legs/leg) 


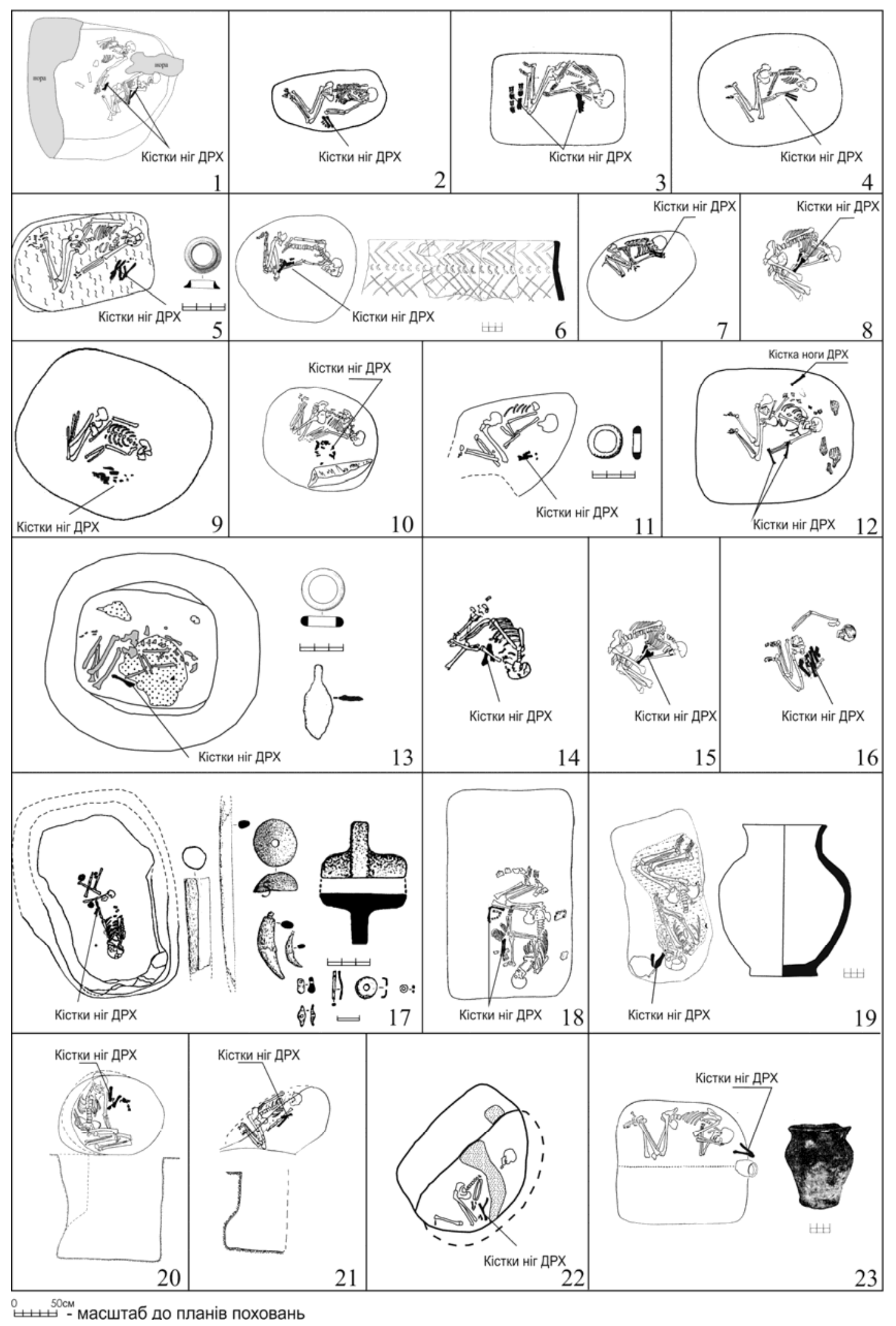

Рис. 3. Поховання з КТ типу 1 (кістки ніг/ноги ДРХ) (продовження):

1 - Миколаївка 3 2/1; 2 - Калинівський 54/2; 3 - Скатівка 21/7; 4 - Скатівка 6/1; 5 - Линьове 6/6; 6 Рунталь $1 / 1 ; 7$ - Крива Лука XXIII 3/3; 8 - Степова IV 3/1; 9 - Волзький 2/11; 10 - Верхній Баликлей 2/2; 11 - Велика Дмитрівка 1/6; 12 - Білокам'янка 3/8; 13 - Верхній Баликлей 4/4; 14 - Калинівський 8/15; 15 Степова IV 3/1; 16 - Верхнє Погромне I 3/8; 17 - Писарівка II 10/2; 18 - Бережнівка I 5/21; 19 - Симонівка 1/1; 20 - Смілівка 3/2; 21 - Верхній Баликлей 4/3; 22 - Совєтське 1 окр. кург/6; 23 - Бережнівка I 4/3

Fig. 3. Burial with animal bones of type 1 (small cattle bones of legs/leg) (continuation) 




Рис. 4. Поховання з КТ типів 2 і 8 (кістки ніг/ноги ВРХ та верхня частина черепа з рогами ВРХ): 1 - Крива Лука XXXIV 2/2; 2 - Висока Гора 5/1;3 - Миколаївка 3 4/1; 4 - Миколаївка 3 3/3; 5 - Крутоярівка 11/3; 6 - Совєтське 1 2/15; 7 - Широкий Карамиш 4/10; 8 - Вертячий 7/25; 9 - Усть-Погожьє 1/2; 10 Білогірське ск. 1/14; 9 - Рибушка 15/2; 10 - Усть-Курдюм 6/1; 11 - Палівський 41/3; 11 - Утьовка V 4/1

Fig. 4. Burial with animal bones, types 2 and 8 (cattle legs/leg bones and upper skull with horns) 
Донецький археологічний збірник. - 2019. - № 22. - С. 21-45.

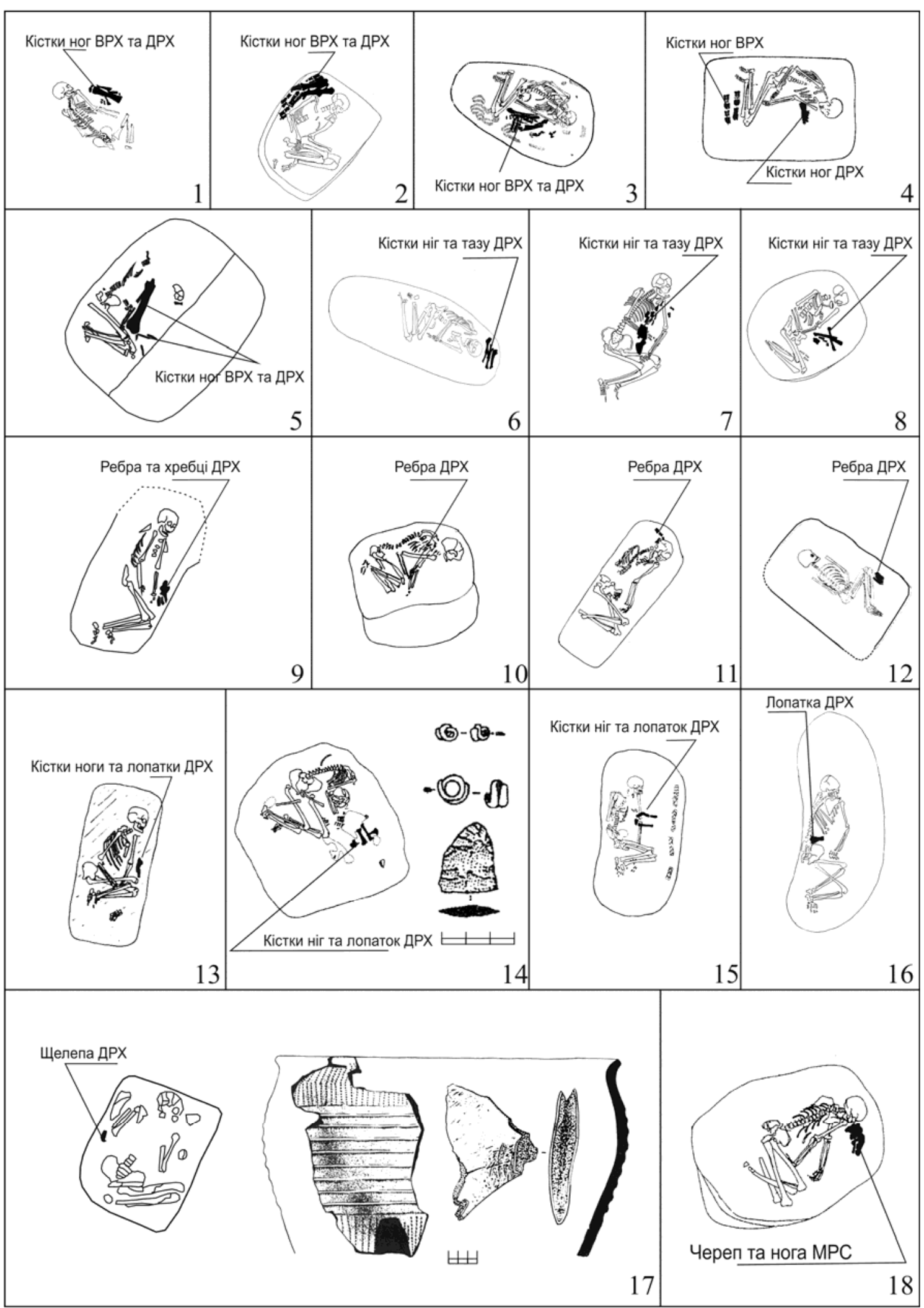

ثн 50 м

Рис. 5. Поховання з КТ типів 7, 9, 10 (лопатка, щелепа, череп і нога ДРХ):

1 - Абганерове III 12/9; 2 - Калинівський 1/4; 3 - Крива Лука XXXIV 5/4; 4 - Скатівка 21/7; 5 Дмитрівка 2/1; 6 - Авіловський 20/6; 7 - Бикове I 4/11; 8 - Линьове 8/2; 9 - Вертячий 7/24; 10 Західні могили 20/5; 11 - Зимняцький $1 / 2 ; 12$ - Власівський 14/1; 13 - Вертячий 7/7; 14 - Світле Озеро 6/3; 15 - Котлубань II 4/2; 16 - Крива Лука XI 4/5; 17 - Царів 66/1; 18 - Смілівка гр. мог. п. 111

Fig. 5. Burial with animal bones, types 7, 9, 10 (shoulder blade, jaw, skull and leg of small cattle) 
Донецький археологічний збірник. - 2019. - № 22. - С. 21-45.

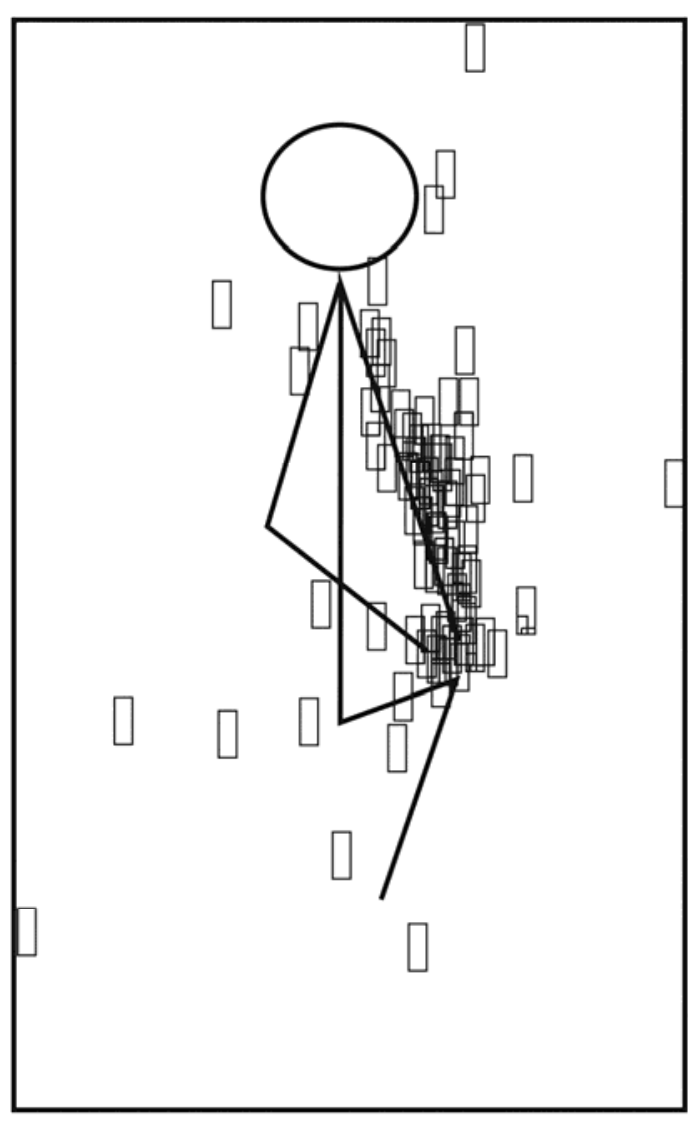

П - кістки ніг/ноги ДРХ

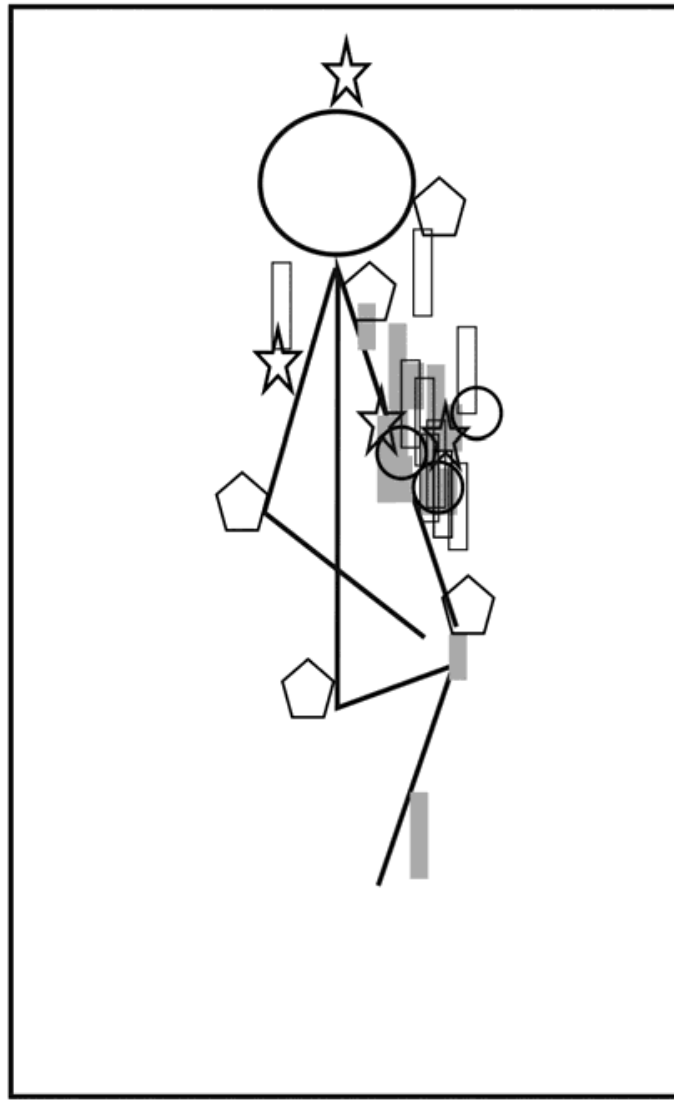

2

Рис. 6. Акумулятивна схема розміщення КТ в похованнях ВДБК:

1 - поховання з КТ типу 1 (кістки ніг ДРХ); 2 - поховання з КТ типів 2-10

Fig. 6. Accumulative scheme of placement of animal bones in the burials of VDBC: $\mathbf{1}$ - burial with animal's bones of type $1 ; \mathbf{2}$ - burial with animal's bones of types 2-10 
Донецький археологічний збірник. - 2019. - № 22. - С. 21-45.

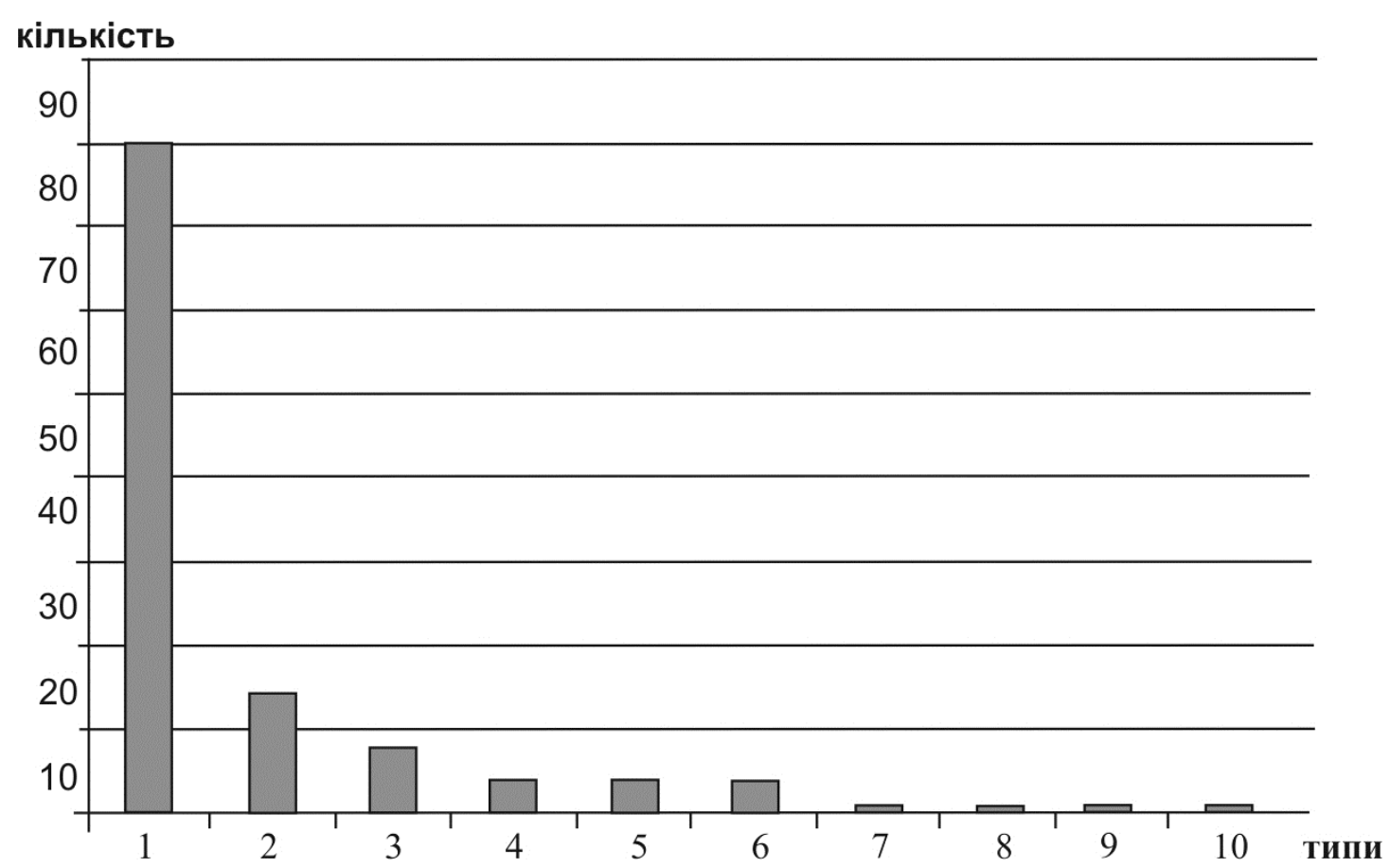

Рис. 7. Кількісне співвідношення поховань ВДБК з різними типами КТ

Fig. 7. Quantitative ratio of VDBC burials with different types of animal bones
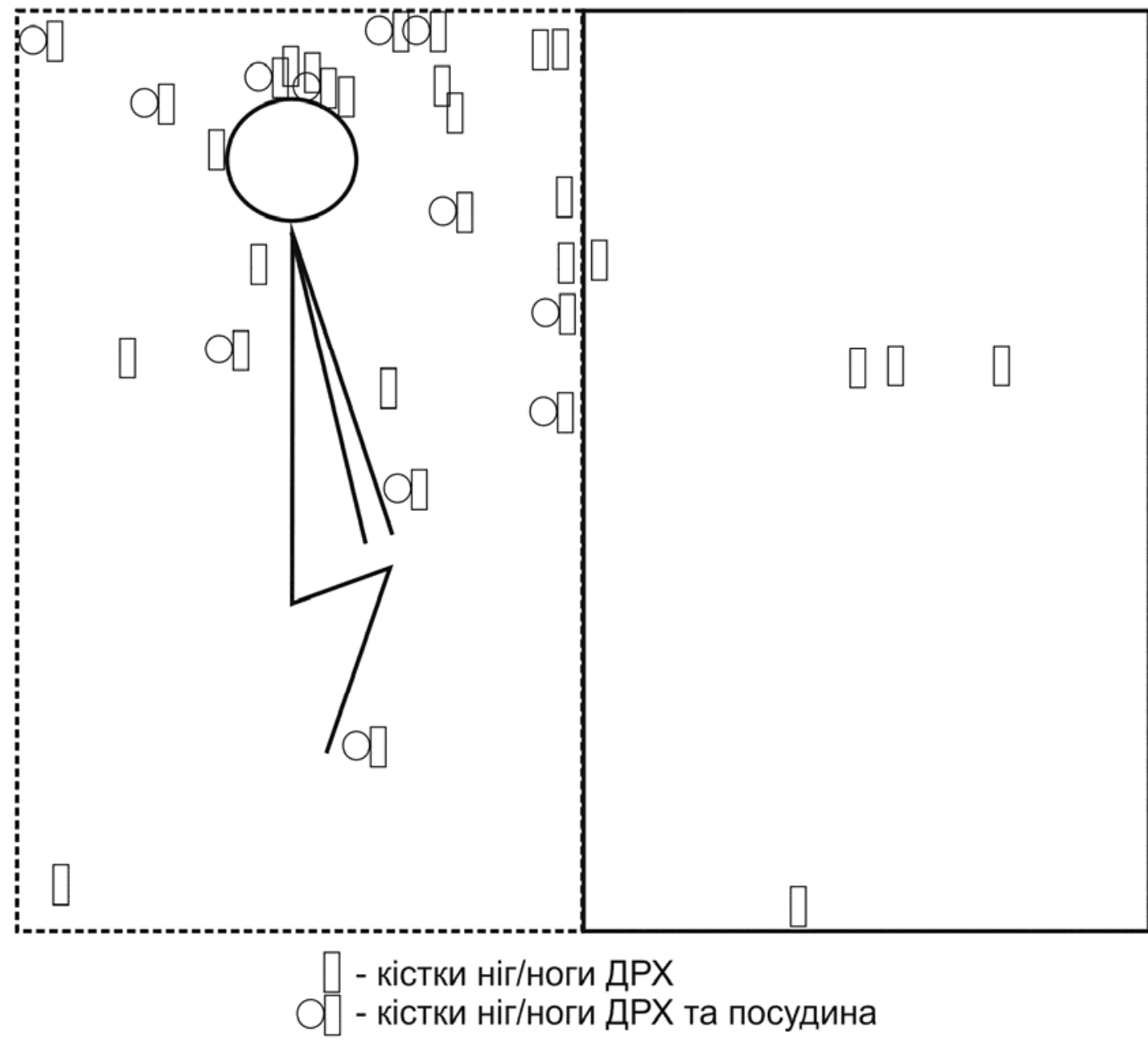

Рис. 8. Акумулятивна схема розміщення КТ в похованнях волго-донської катакомбної культури Fig. 8. Accumulative scheme of placement of animal bones in burials of Volga-Don Catacomb Culture 
Донецький археологічний збірник. - 2019. - № 22. - С. 21-45.

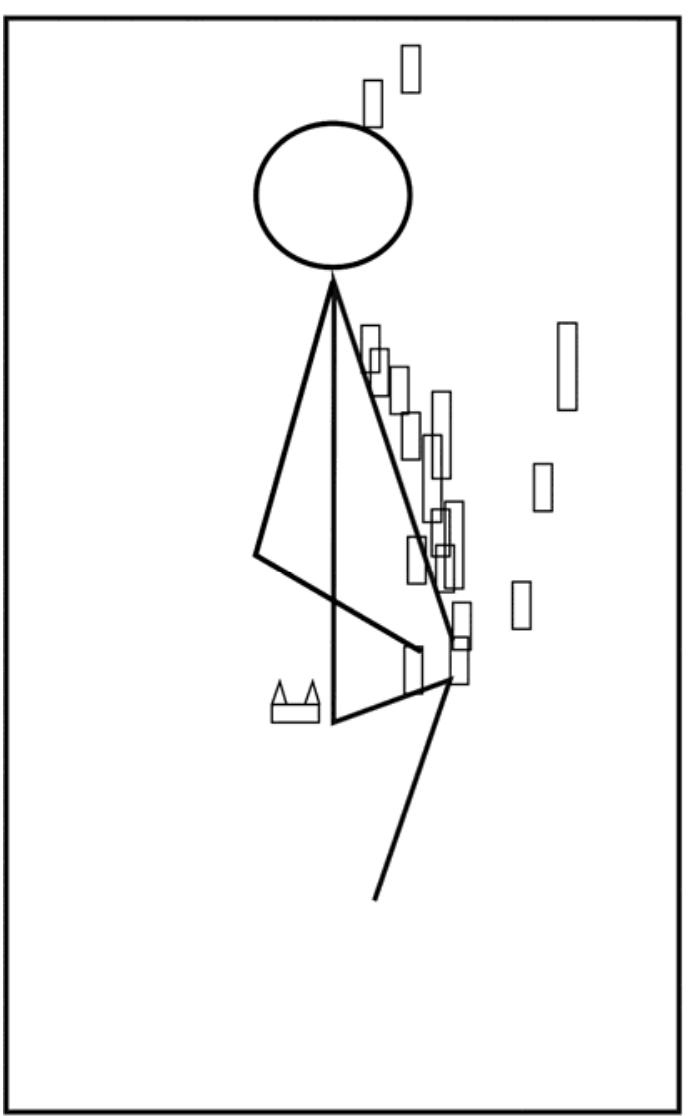

1

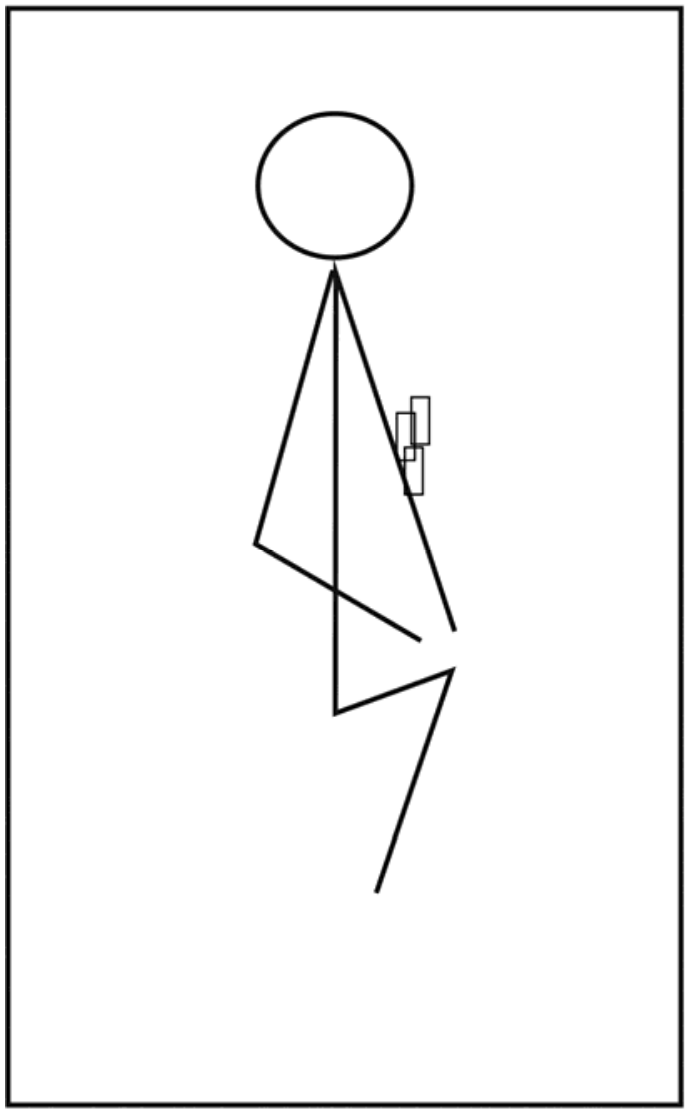

- кістки ніг/ноги ДРХ

- кістки ніг/ноги ВPX

$\triangle A$ - роги та верхня частина
черепа BPX

2

Рис. 9. Акумулятивні схеми розміщення КТ в похованнях ВДБК за етапами: $\mathbf{1}$ - перший етап; $\mathbf{2}$ - другий етап

Fig. 9. Accumulative schemes of placement of animal bones in the burials of VDBC, in stages: $\mathbf{1}$ - the first stage; $\mathbf{2}$ - the second stage 